IZA DP No. 5717

The Welfare Impact of Price Changes on

Household Welfare and Inequality 1999-2010

Jason Loughrey

Cathal O'Donoghue

May 2011 


\title{
The Welfare Impact of Price Changes on Household Welfare and Inequality 1999-2010
}

\author{
Jason Loughrey \\ REDP Teagasc and NUI Galway \\ Cathal O'Donoghue \\ REDP Teagasc and IZA
}
Discussion Paper No. 5717
May 2011

IZA

P.O. Box 7240

53072 Bonn

Germany

Phone: +49-228-3894-0

Fax: +49-228-3894-180

E-mail: iza@iza.org

Any opinions expressed here are those of the author(s) and not those of IZA. Research published in this series may include views on policy, but the institute itself takes no institutional policy positions.

The Institute for the Study of Labor (IZA) in Bonn is a local and virtual international research center and a place of communication between science, politics and business. IZA is an independent nonprofit organization supported by Deutsche Post Foundation. The center is associated with the University of Bonn and offers a stimulating research environment through its international network, workshops and conferences, data service, project support, research visits and doctoral program. IZA engages in (i) original and internationally competitive research in all fields of labor economics, (ii) development of policy concepts, and (iii) dissemination of research results and concepts to the interested public.

IZA Discussion Papers often represent preliminary work and are circulated to encourage discussion. Citation of such a paper should account for its provisional character. A revised version may be available directly from the author. 
IZA Discussion Paper No. 5717

May 2011

\section{ABSTRACT \\ The Welfare Impact of Price Changes on Household Welfare and Inequality 1999-2010}

This paper provides a single welfare measure to show the effects of consumer price changes upon households in Ireland between 1999 and 2010. This measure combines an efficiency component using a Linear Expenditure System (LES) and an equity component using the Atkinson Social Welfare Function. The efficiency component includes the behavioural response to price changes for non-subsistence expenditures thereby producing a Cost of Living Index. The Atkinson Index of Inequality produces an inequality measure and this is combined with the Cost of Living Index to produce an overall welfare measure. This extends upon the existing Irish literature on this issue by accounting for this broader set of components. The results show that changes in the cost of living have differed substantially between households both in terms of demographics and the position of the household in the income distribution and that behavioural response can potentially improve the welfare position of households in response to price changes in most years.

JEL Classification: D12, D31, D63, E31, P46

Keywords: price, inflation, equivalent income, welfare, linear expenditure system, consumer price index, distribution, compensating variation, inequality aversion

Corresponding author:

Cathal O'Donoghue

Rural Economy Research Centre

Teagasc

Athenry, Co. Galway

Ireland

E-mail: Cathal.ODonoghue@teagasc.ie 


\section{INTRODUCTION}

After a decade of relatively low positive price changes, the welfare impact of inflation moved off the policy and research agenda. The recent period of price volatility amongst necessities such as food, fuel and housing costs as well as a recent period of deflation has resulted in increased discussion as to the differential impact of price changes on different socio-economic groups. The public debt crisis in many developed countries has combined with uncertainty about monetary regimes and therefore increased uncertainty about the future direction of the overall price level. This paper attempts to use applied microeconomic research to understand the impact of price changes over the period 1999-2010 in Ireland. However the results produce many insights that can improve knowledge and understanding about the cost of living issue into the future.

The ongoing but intermittent movement in consumer prices combined with the heterogeneous consumption baskets of different households means that the welfare impact of price changes can differ greatly between households over time. The rationale for this paper is to explore the degree to which price changes impacted differently upon the economic welfare of Irish households between 1999 and 2010. Numerous studies in other countries have found substantial differences in changes to the cost of living for different households. These include Hobjin and Lagakos (2005) which found that household-specific inflation rates in the USA between 1987 and 2001 varied substantially around the mean inflation rate. Crawford and Smith (2002) found that from 1976 to 2000, only about one third of households in the United Kingdom faced inflation rates within one percentage point of the average rate in each year.

In Ireland, a recent study by Murphy and Garvey (2004) found that inflation for the urban poor exceeded the state average by a total of almost four per cent for the period between October 1996 and November 2001. Much of the difference is attributed to the increase in rent and accommodation charges and the sharp fall in mortgage interest rates. This widening in the cost of living gap between the urban poor and the state average occurred despite the high inflation for many commodities that form a lower share for the urban poor than the state average. These included entertainment, medical costs, vehicle insurance and motor tax. Food expenditures were among the expenditures for which prices rose the most including tea, fresh fruit and vegetables. Food expenditures are among the most essential expenditures and large price increases for these expenditures is likely to have increased inequality.

Murphy and Garvey (2004) focused purely on the direct welfare impact due to changing prices alone. However, the ability of consumers to alter their consumption basket in response to price changes means that the welfare loss or gain from changing prices can be improved for the consumer. The behavioural response to a price change is less in the case of goods and services with an inelastic demand such as food than for goods with an elastic demand that can be considered luxuries. Therefore a change in the price of the most essential goods has a lower distortionary impact on the composition of the consumption basket. However welfare is affected more in the case of price changes for inelastic goods 
and services because the consumer is less willing or able to derive utility from transferring to the relatively cheaper alternatives post-price change. ${ }^{1}$

This paper departs from the work of Murphy and Garvey (2004) by measuring the welfare change due to price changes both from the direct impact but also from the indirect impact due to substitution behaviour. Murphy and Garvey (2008) did account for behavioural response by producing Superlative Cost of Living Indices (Fisher and Tornqvist) and found the counterintuitive result that the behavioural response of consumers to price increases led to even greater welfare losses than those calculated using the Consumer Price Index. The calculation of Superlative Cost of Living Indices is beyond the scope of this paper as we use a demand system instead. Sommerville (2004) found a low substitution bias in the CPI of about 0.02 per annum using the Almost Ideal Demand System model and found that the growth of the superlative indices actually exceeded the CPI for approximately half of the period between 1988 and 2001. Sommerville found that the size of the substitution bias for the AIDS model corresponds closely to that of Irvine and McCarthy (1978).

A welfare measure must be employed in order to calculate the degree of substitution behaviour and therefore substitution bias in the index. Uncompensated welfare measures such as consumer surplus are usually considered an insufficient basis for welfare measurement. The main alternatives available are the Hicksian compensated welfare measures of equivalent variation and compensating variation. In this case, the compensating variation is chosen as the welfare measure because it is with reference to restoring original utility. Hicksian compensated welfare measures should only be used from an ethical point of view if there is a realistic opportunity for the consumer to be compensated in income for the price increase. The calculation of price indices for different household groups and income deciles can potentially inform policymakers to a greater extent about cost of living changes for specific household types and therefore improve the likelihood of compensation taking place.

In order to calculate compensating variation, we utilise data from the Household Budget Survey, together with a demand system containing elasticities of the response of households to price and income changes to produce behaviour adjusted welfare measures of price changes in Ireland. The transition from private household welfare change to societal welfare change is made using a social welfare function which accounts for inequality aversion.

The paper has the following outline. Section 2 describes the methodology used in the study. Section 3 outlines the price data and budget survey data used in the study. Section 4 follows providing the Distributional Characteristic for different commodities. Section 5 provides the Compensating Variation for different demographic groups and consumption deciles in all years from 1999 to 2010 and the overall welfare effect in each year. This is followed by the conclusions.

\footnotetext{
${ }^{1}$ We calculate the substitution effect of price changes to account for consumers that change their behaviour in response to changes in consumer prices ${ }^{1}$. In contrast to theoretical expectations, Murphy and Garvey (2004) found that poorer households in Ireland displayed more substitution activity.
} 


\section{Methodology}

The tendency for consumers to substitute between goods in response to price changes has implications for the measurement of the welfare result. A welfare measure that does not account for this substitution behaviour will overestimate the welfare loss from a price increase and underestimate the welfare gain from a price decrease in a given commodity. This is due to the responsive behaviour of the consumer in responding to differential price changes between goods. A measurement of welfare change must therefore account for this substitution behaviour.

Measuring the impact of substitution behaviour upon consumer welfare can be done using a demand system, which report own and cross price elasticities as well as income elasticities for each of the consumption goods. There are a number of alternative demand systems that can be used to calculate price elasticities of demand and therefore the overall welfare change from price changes. These include the Almost Ideal Demand System (AIDS) of Deaton and Muellbauer (1980), the Rotterdam (ROTT) system of Theil (1975) and the LES of Stone (1954). The AIDS and ROTT models are broadly similar (Barnett and Seck, 2006). Both models require a supply of price and expenditure data from distinct time periods or geographical areas.

The suitability of these demand systems for this form of price analysis is dependent on the extent of price variation during the time period of the study. We have potentially 10 quarters of price data that are suitable for this analysis i.e. five quarters each from the 1999/2000 and 2004/2005 household budget surveys. Bargain et.al (2009) explain that little price variation is found in the 2004/2005 price data. This reduces the potential performance of the AIDS model for the calculation of elasticities. When there is limited price and expenditure data, the LES method, although relatively crude, can be used to derive estimates of the elasticities required for the analysis. The LES methodology is based on the explicit use of direct utility functions and is therefore parametric. This study tries to overcome problems relating to population heterogeneity by using different household groups with separate parameters calculated for each group thereby producing twelve representative households. The methodology used to calculate the private household welfare change is based upon the calculation of Equivalent Income.

\section{Equivalent Income}

Equivalent income is our measure of post price change utility $\left(y_{e}^{h}\right)$; a concept due to King (1983) - the total expenditure that at some set of new prices $p_{r}$ and given characteristics gives the same utility as that derived from original price $\mathrm{p}$. In our case, the new prices are the post-change prices.

Hence the indirect utility function with the new prices $\left[\mathrm{V}\left(\mathrm{p}_{\mathrm{r}}, \mathrm{y}_{\mathrm{e}}, \mathrm{z}\right)\right]$ is equal to the indirect utility with the original prices and income $[\mathrm{V}(\mathrm{p}, \mathrm{y}, \mathrm{z})]$ for a household with income $\mathrm{y}$ and demographic characteristics $\mathrm{z}$. The reference demographic group is a single adult living alone with no children and lower secondary education.

Equivalent income is therefore:

$$
y_{e}^{h}=E\left(p_{r}, V(p, y, z), z\right)
$$


where $\mathrm{E}()$ is an expenditure function (i.e. the expenditure necessary with prices $\mathrm{p}_{\mathrm{r}}$ to have utility $\mathrm{V}()$ with demographic characteristics $\mathrm{z}$ ). It is the income necessary for utility to remain the same for households when prices change.

The compensating variations produced by the LES are the welfare losses from changes in the absolute price level. The Compensating Variation is calculated by subtracting actual consumption from equivalent income. The use of equivalent income was examined by King (1983). Equivalent income is defined as the value of income, $y_{e}^{h}$, which at some set of reference prices, $\mathrm{p}_{\mathrm{r}}$ and consumer preferences gives the same level of utility as the actual or original level of income pre-price change.

$$
\mathrm{CV}=\mathrm{ye}-\mathrm{c}
$$

In this case, equivalent income is the amount of income that would provide the same level of utility as that from original income but at the new price level. Therefore in the case of an increase in the overall price level, equivalent income will lie above that of actual income. An earlier discussion of this concept was provided by Roberts (1980).

\section{Utility Function}

In order to produce equivalent income, we require a utility function. As in the case of Creedy (2001), we utilise a Stone-Geary LES direct utility function for a:

$$
U=\prod_{i}\left[x_{i}-\gamma_{i}\right]^{\phi_{i}}
$$

where $\gamma_{i}$ are LES parameters known as committed consumption for each good $\mathrm{i}$ and the marginal budget shares ${ }^{2} 0 \leq \phi_{i} \leq 1, \sum_{i} \phi_{i}=1$. The calculation of committed or subsistence consumption is the key motivation for the use of the Stone Geary function. The Engel curves are linear but do not travel through the origin. Therefore substitution behaviour is assumed to only take place for those expenditures which lie above the level of committed or subsistence consumption. The higher the level of subsistence income relative to total expenditure, the lower the scope exists to gain from substitution behaviour in response to price changes.

Deaton (1974) critiques the assumption of additivity which is present in the LES. Creedy (1998) explains that the high degree of structure imposed by additive utility functions does not allow for complementary goods and requires approximate proportionality between income and price elasticities but regards these as the costs of overcoming data limitations. Creedy and Van de Ven (1996) advise that potential problems are much less severe when broad commodity groups are used. Other studies to have used the LES include Madden (1995), Powell (1974) and Dixon and Lluch (1982).

\footnotetext{
2 The marginal budget shares are the proportion of the additional unit of expenditure spent on each of the 21 commodities. The marginal budget share for necessities usually fall below the average budget share for those most necessary commodities.
} 
For convenience we ignore the subscripts, $z$ indicating that different parameters are estimated for different demographic groups. Maximising utility subject to the budget constraint $C=\sum_{i} p_{i} x_{i}$, the linear expenditure function for good $\mathrm{i}$ is:

$$
p_{i} x_{i}=p_{i} \gamma_{i}+\phi_{i}\left(C-\sum_{j} p_{j} \gamma_{j}\right)
$$

Differentiating w.r.t. $p_{i}$ and multiplying by $\frac{p_{i}}{p_{i} x_{i}}$, we produce the own price elasticity from which the $\gamma_{i}$ parameters (subsistence expenditures) can be derived:

$$
\begin{aligned}
& \eta_{i i}=\frac{p_{i} \gamma_{i}}{p_{i} x_{i}}-\frac{p_{i} \phi_{i}}{p_{i} x_{i}}\left(\gamma_{i}\right)=\frac{\gamma_{i}\left(1-\phi_{i}\right)}{x_{i}}-1 \\
& \Rightarrow \gamma_{i}=\frac{\left(\eta_{i i}+1\right) x_{i}}{\left(1-\phi_{i}\right)}
\end{aligned}
$$

Differentiating (5) w.r.t. $C$ and multiplying by $\frac{C}{p_{i} x_{i}}$, we produce the budget elasticity, from which we can derive the $\phi_{i}$ parameters:

$$
\eta_{i}=\frac{\phi_{i} C}{p_{i} x_{i}}
$$

Implies that the marginal budget shares are

$$
\phi_{i}=\frac{\eta_{i} c_{i}}{C}=\eta_{i} w_{i}
$$

We can produce the indirect utility function of the LES by substituting into the direct utility function (4), the Marshallian demand function:

$$
\begin{aligned}
& V(p, y)=\prod_{i}\left[\gamma_{i}+\frac{\phi_{i}}{p_{i}}\left(C-\sum_{j} p_{j} \gamma_{j}\right)-\gamma_{i}\right]^{\phi_{i}} \\
& =\prod_{i}\left[\frac{\phi_{i}}{p_{i}}\left(C-\sum_{j} p_{j} \gamma_{j}\right)\right]^{\phi_{i}}=\frac{\prod_{i}\left[C-\sum_{j} p_{j} \gamma_{j}\right]^{\phi_{i}}}{\prod_{i}\left[p_{i} / \phi_{i}\right]^{\phi_{i}}} \\
& =\frac{C-\sum_{j} p_{j} \gamma_{j}}{\prod_{i}\left[p_{i} / \phi_{i}\right]^{\phi_{i}}}
\end{aligned}
$$

Cross-multiplying, the LES expenditure function for price $\mathrm{p}_{\mathrm{i}}$ is: 


$$
E(p, U, z)=C=\sum_{i} p_{i} \gamma_{i}+\prod_{i}\left(p_{i} / \phi_{i}\right)^{\phi_{i}} V(p, y)
$$

While the expenditure function for price $\mathrm{p}_{\mathrm{r}, \mathrm{i}}$ is:

$$
E\left(p_{r}, U, z\right)=\sum_{i} p_{r, i} \gamma_{i}+\prod_{i}\left(p_{r, i} / \phi_{i}\right)^{\phi_{i}} U
$$

Where $U=V(p, y)$

Hence from (8) and (10) we can produce the equivalent income necessary to produce utility $\mathrm{U}$ (based upon consumption $\mathrm{C}$ and price $\mathrm{p}_{\mathrm{i}}$ ), when prices are $\mathrm{p}_{\mathrm{r}, \mathrm{i}}$.

$$
\begin{aligned}
& y_{e}=\sum_{i} p_{r, i} \gamma_{i}+\prod_{i}\left(p_{r, i} / \phi_{i}\right)^{\phi_{i}} \cdot \frac{C-\sum_{i} p_{i} \gamma_{i}}{\prod_{i}\left(p_{i} / \phi_{i}\right)^{\phi_{i}}} \\
& =\sum_{i} p_{r, i} \gamma_{i}+\left[\prod_{i}\left(p_{r, i} / p_{i}\right)^{\phi_{i}}\right]\left[\left[C-\sum_{i} p_{i} \gamma_{i}\right]\right.
\end{aligned}
$$

\section{Social Welfare Calculation}

In order to scale up the individual impacts on welfare of a price change, we utilise a social welfare function. If citizens are indifferent to the differential inequality impact of price changes, then the sum of private household welfare gains or losses will equal the total change to societal welfare. In the presence of societal inequality aversion, citizens are concerned about the inequality impact of price changes outside of their own private welfare, which can be captured by a social welfare function. As in the case of Madden (1995), we utilise a variant of the Atkinson (1970) social welfare function:

$$
W=\frac{1}{H} \sum_{h} \frac{\left(v^{h}\right)^{1-e}}{1-e} .
$$

Where $\mathrm{H}$ is the number of households and $\mathrm{e}$ is the inequality aversion parameter that relates to how much a transfer from rich to poor will improve social welfare; the higher the value of e the more a transfer will improve welfare $^{3}$. This formula implies that additional consumption provides greater additional utility for poorer than richer households. This means that the same price increase has a more adverse welfare impact upon poorer than richer households. The degree to which inflation and thereby welfare affects poorer households depends in part upon the degree of inequality aversion that exists in society and the relative composition of consumption baskets for poorer households.

\footnotetext{
${ }^{3}$ In the case of there being two person society with one individual having twice the income of another, an inequality aversion parameter of 0.3 indicates that total welfare is improved by a one euro transfer from rich to poor so long as the amount lost in the transaction is less than 19 cent. For an inequality aversion parameter of 0.8 , the transfer improves total societal welfare so long as the long as the amount lost in the transaction is less than 42.5 cent. Amiel et. al (1999) find that measures of inequality aversion can be obtained with some precision and calculate a value of 0.3 for students in Australia. Blinder (1978) found that inequality aversion for U.S. citizens is in the range of 0.1 to 0.2 .
} 
Excluding the inequality aversion parameter, we assume that utility for each household equals consumption, $v^{h}=c^{h}$. Including the inequality aversion parameter means that a change in $v^{h}$ or $c^{h}$ results in the following: $\theta^{h}=\frac{\partial W}{\partial c^{h}}=\frac{1}{H}\left(c^{h}\right)^{-e}$

Atkinson's measure of inequality is

$$
A(e)=1-\left[\frac{\left[\left(\frac{1}{H}\right) \cdot \sum_{h}\left(y_{e}^{h}\right)^{(1-e)}\right]^{1 /(1-e)}}{\bar{y}_{e}}\right]=1-\left[\frac{y_{\text {ede }}}{\bar{y}_{e}}\right]
$$

For our purposes, we assume that $y^{h}=c^{h}=v^{h}$ i.e. that total household income equals total expenditure. This restriction means that savings are ignored. Combining this with our Social Welfare Function W, we produce a Social Welfare Function based upon equivalent income:

$$
W=\frac{1}{H} \sum_{h} \frac{\left(y_{e}^{h}\right)^{1-e}}{1-e}=\frac{\left(y_{\text {ede }}\right)^{1-e}}{1-e}
$$

where $y_{\text {ede }}=\bar{y}_{e}(1-A(e))$ and $\bar{y}_{e}$ is the mean equivalent income and $A(e)$ is Atkinson's inequality of equivalent income. $y_{\text {ede }}$ the equally distributed equivalent value can be interpreted as the equivalent income that if distributed equally across the population produces the same value of social welfare as the existing distribution of income. It captures the trade-off between equity and efficiency. The higher $y_{\text {ede }}$ the higher the product of mean equivalent income (efficiency) and equality, hence an increase in equality or efficiency can increase $y_{\text {ede }}$.

\section{DATA}

\section{Expenditure Data}

In order to produce our welfare estimates and derive our demand system, we require micro data that contains expenditure at the household level. We use the Irish Household Budget Survey (HBS) data of 1999/2000 and 2004/2005 for this study. There are 7644 households and 525 expenditure items (expenditure greater than zero) in the 1999/2000 HBS. There are 6884 households and 805 expenditure items (expenditure greater than zero) in the 2004/2005 HBS. These expenditure items are divided into twenty-one commodity groups.

The choice of grouped budget shares has the following advantages: 
- It reduces the impact of the zero expenditures problem, which could substantially undermine the results of OLS regressions. ${ }^{4}$

- $\quad$ Estimates for smaller groups of goods could be unstable.

- $\quad$ In any case, twenty-one categories are a number sufficient to allow for a substantial degree of heterogeneity in inflation and consumption behaviour.

- $\quad$ Total Consumption for this study is defined as the monetary value of non-durable and durable goods and services purchased during the period of the survey5.

\section{Price Data}

The increases in the overall CPI from 1999-2010 (table 4) are considered low by most economists and are much lower than those experienced during the 1970s and early 1980s. However considerable divergence between commodity group inflation rates exists so that the welfare impact of changing prices may differ greatly between different households and income levels over time.

The price data is taken from the CSO. This data provides the annual price level for twentyone commodity groups from 1998 to 2010. The price inflation for each commodity is calculated with the same method as the overall Consumer Price Index, a Laspeyres Price Index. In addition, we calculate the cost of living Index using the Linear Expenditure System (LES). We use the price level for 1998 to calculate the increase in the cost of living for 1999. The use of only twenty-one commodity groups does not pose major problems because the LES is best using a small number of commodity groups. However an important assumption is that there is no price variation within commodity groups and the substitution effect within commodity groups is not calculated because of the limitations posed by the LES method. The calculation of the commodity group inflation rates is done by subtracting the current year's price level $\mathrm{p} 1$ from the previous year $\mathrm{p} 0$ and dividing this by the price level of the previous year p0.

$$
((p 1-p 0) / p 0)
$$

\section{Estimating Budget and Price Elasticities}

The price elasticities are required to calculate the subsistence level of expenditure for each good which is given in equation 5 . The price elasticities of demand are calculated using the OLS regression method in equation 17. A commodity with a low price elasticity of demand of approximately -0.2 will result in a high level of subsistence expenditure for that commodity. In contrast, high price elasticities of demand will result in a low level of

\footnotetext{
4 A zero expenditure, can be due not only to infrequent purchases, but also to abstention from consumption: this is a problem relevant only for a few goods of our list (alcohol and tobacco); we deal with this problem for tobacco by including a smoker variable in the demographic characteristics. We find that the exclusion of the zero expenditures has minimal impact on the size of the behavioural response component in the model so that it is not a major issue. The inclusion of independent variables such as smoker, car owner and mortgage holder help overcome the limitations posed by zero expenditures. We make no adjustment for alcohol. These are listed in the Appendix Table A1.
}

\footnotetext{
${ }^{5}$ This definition does not include: The imputed rents for home owners and the value of houses eventually purchased, The amounts paid for direct taxes or social security contributions, The value of home production, The value of debt repayment (interest repayments are included), The value of gifts received (but includes contribution to churches or associations, etc.).
} 
subsistence expenditure and in many cases zero where the price elasticity of demand is less than -1 i.e. elastic.

The price elasticity of demand,

$$
\eta_{k, i}^{h}=\frac{\delta x_{k}^{h}}{\delta p_{i}} \frac{p_{i}}{x_{i}^{h}}
$$

Creedy (2001) describes an approximate method for producing price elasticities. Rather than estimating a system of demand equations, it relies on a method due to Frisch (1959) that describes own and cross-price elasticities in terms of total expenditure (budget) elasticities $\left(\eta_{i}\right)$, budget shares $\left(\mathrm{w}_{\mathrm{i}}\right)$ and the "Frisch" marginal utility of income parameter $(\xi)$ for directly additive utility functions. ${ }^{6}$ The calculation of the Frisch parameter is reported in the Appendix. This can be described as follows:

$$
\eta_{i j}=-\eta_{i} w_{j}\left(1+\frac{\eta_{j}}{\xi}\right)+\frac{\eta_{i} \delta_{i j}}{\xi},
$$

where $\delta_{\mathrm{ij}}=1$ if $\mathrm{i}=\mathrm{j}, 0$ otherwise and $w_{j}=\frac{p_{j} C_{j}}{C}$ is the budget share for good $\mathrm{j}$ (See Creedy, 2001 for more details).

In order to calculate the budget elasticities, consumption on particular goods is estimated as budget shares of total consumption, utilising Engle functions.

$$
w_{i}=\alpha+\beta_{1} \ln C_{H B S}+\delta X_{H B S}
$$

where $w_{i}=$ ith budget share, $\mathrm{C}$ is total non durable consumption and $\mathrm{X}$ is the same set of demographic characteristics used above.

The coefficients produced by equation 17 are included in Table A.6a and Table A.6b. One can see from Table A.6a that the negative sign for the log of consumption (lcgrp1-lcgrp12) ${ }^{7}$ significantly reduces the proportion of expenditure devoted to food. This means that an additional unit of total expenditure will lead to a significant decline in the food share using the average household total expenditure as the baseline. This is not surprising given that food is a necessity and the food share should decline as total expenditure rises. The other highly inelastic goods include communications, local authority rents, refuse collection, electricity, natural gas, liquid fuels and solid fuels. All of these commodity groups are negatively related to the log of consumption in the budget share regressions (Tables A6a and A6b). Therefore an increase in total expenditure leads to a decline the budget share for each commodity.

\footnotetext{
${ }^{6}$ Note an additive utility function is utilised which does not allow for complements and so one must exert a degree of caution over the results.

${ }^{7}$ The log of consumption for each household group (lcgrp) is calculated and the attached number corresponds to the number of the household group
} 
The log of consumption is positively and significantly related to a number of commodity groups including clothing, furniture, health, transport, education and restaurants. A unit increase in total expenditure will lead to an increase in the proportion of expenditure devoted to these expenditures. Table 2 shows that most of these commodities are a greater proportion of total expenditure for higher income households. These commodities are shown to be among the most elastic commodity groups (table 3).

The independent variables in the budget share regression manage to capture some of the variation in budget share that is not due simply to changes in total expenditure. Tables A6a and A6b show that being a smoker is associated with a number of expenditures including a reduction in the proportion of expenditure spent on food, clothing, health, furniture and household maintenance and an increase in the proportion spent on local authority rents. Car ownership is positively associated with health and mortgage interest shares and negatively associated with the share for food, alcohol and tobacco, clothing, furniture and household maintenance and communications.

Being an employee is negatively associated with the share for rents, alcohol and tobacco and positively associated with mortgage interest repayments. Being self-employed is positively associated with the food share, mortgage interest and negatively associated with rents. Employment is therefore a clear contributory factor in the size of the mortgage interest repayment. Being a pensioner is positively related to mortgage interest and negatively to rents. The education of the household head is negatively related to the food share for both university and upper secondary. The same is true for the transport share while health, communications and private rents are all positively associated with the household head having upper secondary or university level education.

The number of children in the household is positively associated with the share for food and electricity and negatively associated with the share for restaurants with some variation in the significance of the latter according to the age bracket of the children. This suggests that households with children substitute away from restaurant expenditure towards home cooking. The number of adults over 64 years old is positively related at the one per cent level to the food share and negatively to rents and electricity. The number of earners is negatively related to the food share, education and positively to restaurants.

Table 3: Budget Share Elasticity and Price Elasticity of Demand for Twenty-One Commodity Groups: 1999 and 2004 Budget Surveys

\begin{tabular}{|l|l|l|l|l|l|}
\hline & Budget Year & \multicolumn{2}{|c|}{1999} & \multicolumn{2}{c|}{2004} \\
\hline & & $\begin{array}{l}\text { Budget } \\
\text { Elasticity }\end{array}$ & $\begin{array}{l}\text { Price } \\
\text { Elasticity }\end{array}$ & $\begin{array}{l}\text { Budget } \\
\text { Elasticity }\end{array}$ & $\begin{array}{l}\text { Price } \\
\text { Elasticity }\end{array}$ \\
\hline 1 & Food & 0.21 & -0.17 & 0.25 & -0.20 \\
\hline 2 & Alcohol and Tobacco & 1.07 & -0.74 & 1.02 & -0.75 \\
\hline 3 & Clothing & 1.59 & -1.08 & 1.41 & -1.01 \\
\hline 4 & Furniture and Household Maintenance & 1.29 & -0.89 & 1.34 & -0.96 \\
\hline 5 & Health & 1.69 & -1.15 & 1.50 & -1.06 \\
\hline 6 & Transport & 1.27 & -0.89 & 1.26 & -0.92 \\
\hline 7 & Communications & 0.43 & -0.30 & 0.57 & -0.42 \\
\hline 8 & Leisure & 1.04 & -0.73 & 1.14 & -0.83 \\
\hline 9 & Education & 1.45 & -0.98 & 1.40 & -0.99 \\
\hline 10 & Restaurant & 1.40 & -0.96 & 1.28 & -0.92 \\
\hline 11 & Other & 1.22 & -0.84 & 1.16 & -0.84 \\
\hline 12 & Local Authority Rents & -0.31 & 0.23 & -0.08 & 0.07 \\
\hline
\end{tabular}




\begin{tabular}{|l|l|l|l|l|l|}
\hline 13 & Private Rents & 0.65 & -0.46 & 0.74 & -0.54 \\
\hline 14 & Mortgage Interest & 0.81 & -0.58 & 0.82 & -0.60 \\
\hline 15 & Materials for Maintenance \& Repair of Dwelling & 1.67 & -1.14 & 1.63 & -1.15 \\
\hline 16 & Services for Maintenance and Repair of Dwelling & 0.83 & -0.57 & 1.20 & -0.86 \\
\hline 17 & Refuse Collection & 1.43 & -0.96 & 0.25 & -0.18 \\
\hline 18 & Electricity & 0.08 & -0.05 & 0.06 & -0.04 \\
\hline 19 & Natural Gas & 0.90 & -0.61 & 0.83 & -0.59 \\
\hline 20 & Liquid Fuels & 0.05 & -0.03 & -0.08 & 0.07 \\
\hline 21 & Solid Fuels & -0.87 & 0.62 & -0.46 & 0.35 \\
\hline
\end{tabular}

\section{REsults I: Distributional CHARACTERISTICS}

Before undertaking our behavioural analysis, we firstly undertake a descriptive analysis of the distributional characteristics of the expenditure groups we are analysing in this study. To do this we utilise a measure known as the distributional characteristic used in Newbery (1995), Liberati (2001). The distributional characteristic is based upon a static analysis of the distribution of expenditure over the population and the welfare weights placed upon different groups. It is based on a Social Welfare Function (SWF) W $=\left(v^{1}, \ldots, v^{H}\right)$, where $v^{\text {h }}$ $=\mathrm{v}^{\mathrm{h}}\left(\mathrm{c}^{\mathrm{h}}, \mathrm{p}\right)$ is the indirect utility function of household $\mathrm{h}$ for expenditure $\mathrm{c}$ and prices $\mathrm{p} .8$

We define the impact of change in price as follows:

$$
\frac{\partial W}{\partial p_{i}}=\sum_{h} \frac{\partial W}{v^{h}} \cdot \frac{\partial v^{h}}{\partial p_{i}}=\sum_{h} \frac{\partial W}{v^{h}} \cdot \frac{\partial v^{h}}{\partial c_{i}^{h}} \cdot \frac{\partial c_{i}^{h}}{\partial p_{i}}=-\sum_{h} \theta^{h} x_{i}^{h}
$$

where $\theta^{h}=\frac{\delta W}{\delta v^{h}} \cdot \frac{\delta v^{h}}{\delta c_{i}^{h}}$ and $c_{i}^{h}=p_{i} x_{i}^{h}, \theta^{h}$ is the social marginal utility of total expenditures for household $\mathrm{h}$ and $x_{i}^{h}$ is the consumption of good $\mathrm{i}$ by household $\mathrm{h}$.

$$
d_{i}=\frac{\sum_{h} \theta^{h} c_{i}^{h}}{\bar{\theta} \sum_{h} c_{i}^{h}}
$$

where $\bar{\theta}$ is the average social welfare weight. The more a good is consumed by households with higher social marginal utilities (social weight), the higher is $d_{i}$. If however we apply constant social welfare weights (i.e. we are indifferent between households of different income), then $d_{i}=1, \forall i$.

We report the Distributional Characteristics of each commodity to provide some context as to the potential impact of price changes in different commodity groups from a purely distributional perspective. The following results indicate the relative desirability of price increases in twenty-one commodity groups from a purely distributional perspective. The DC results are presented below for the 1999 and 2004 household budget surveys using two levels of inequality aversion.

\footnotetext{
${ }^{8}$ For a more detailed description of this method, see Liberati (2001).
} 
The higher distributional statistics (lower ranked) imply that these goods are purchased more intensively by poorer households. There are few changes in the rankings in response to different levels of inequality aversion in both years. The results for 1999 and 2004 show that local authority rents is the commodity consumed most intensively by poorer households relative to richer households. Food, solid and liquid fuels are among the other commodities consumed most intensively by poorer households. Education, mortgage interest and transport are the commodities consumed most intensively by richer households.

The big changes between 1999 and 2004 are that expenditures on furniture and household maintenance, communications, alcohol, tobacco and mortgage interest spending became more concentrated among richer households i.e. spending on these commodities came more from richer households. Restaurant, refuse collection, clothing and transport expenditures became more concentrated among poorer households. The results suggest that price increases for local authority rents, food, electricity, solid and liquid fuels impact greater upon the welfare of poorer households than for richer households. The results also suggest that price increases for education, mortgage interest, furniture and household maintenance impact greater upon the welfare of richer households than for poorer households. 
Table 4: Distributional Characteristic 1999 and 2004

\begin{tabular}{|l|l|l|l|l|l|l|l|l|}
\hline & $\begin{array}{l}1999 \\
(0.3)\end{array}$ & Rank & $\begin{array}{l}1999 \\
(0.8)\end{array}$ & Rank & $\begin{array}{l}2004 \\
(0.3)\end{array}$ & Rank & $\begin{array}{l}2004 \\
(0.8)\end{array}$ & Rank \\
\hline Local Authority Rents & 1.07 & 1 & 1.20 & 1 & 1.09 & 1 & 1.26 & 1 \\
\hline Solid Fuels & 1.04 & 2 & 1.09 & 2 & 1.03 & 2 & 1.06 & 2 \\
\hline Electricity & 0.97 & 4 & 0.93 & 4 & 0.98 & 3 & 0.94 & 3 \\
\hline Food & 0.98 & 3 & 0.94 & 3 & 0.98 & 4 & 0.94 & 4 \\
\hline Liquid Fuels & 0.97 & 5 & 0.91 & 5 & 0.98 & 5 & 0.93 & 5 \\
\hline Refuse Collection & 0.92 & 10 & 0.80 & 10 & 0.97 & 6 & 0.91 & 6 \\
\hline Private Rents & 0.93 & 9 & 0.81 & 9 & 0.96 & 7 & 0.89 & 7 \\
\hline Natural Gas & 0.93 & 8 & 0.83 & 8 & 0.95 & 8 & 0.87 & 8 \\
\hline Communications & 0.95 & 6 & 0.86 & 6 & 0.95 & 9 & 0.86 & 9 \\
\hline Alcohol and Tobacco & 0.94 & 7 & 0.84 & 7 & 0.94 & 10 & 0.84 & 10 \\
\hline Restaurant & 0.90 & 13 & 0.75 & 14 & 0.91 & 11 & 0.77 & 11 \\
\hline Leisure & 0.92 & 11 & 0.79 & 11 & 0.91 & 12 & 0.78 & 12 \\
\hline Other & 0.90 & 15 & 0.74 & 15 & 0.90 & 13 & 0.76 & 13 \\
\hline Clothing & 0.89 & 17 & 0.72 & 16 & 0.90 & 14 & 0.76 & 14 \\
\hline $\begin{array}{l}\text { Services for Maintenance and } \\
\text { Repair of Dwelling }\end{array}$ & 0.91 & 12 & 0.78 & 12 & 0.89 & 15 & 0.75 & 15 \\
\hline $\begin{array}{l}\text { Furniture and Household } \\
\text { Maintenance }\end{array}$ & 0.90 & 14 & 0.76 & 13 & 0.89 & 16 & 0.74 & 16 \\
\hline Transport & 0.88 & 20 & 0.72 & 20 & 0.89 & 17 & 0.73 & 17 \\
\hline Education & 0.89 & 16 & 0.72 & 17 & 0.89 & 18 & 0.72 & 18 \\
\hline Health & 0.88 & 21 & 0.71 & 21 & 0.88 & 19 & 0.72 & 19 \\
\hline $\begin{array}{l}\text { Materials for Maintenance \& } \\
\text { Repair of Dwelling }\end{array}$ & 0.89 & 19 & 0.72 & 18 & 0.86 & 20 & 0.68 & 20 \\
\hline Mortgage Interest & 0.89 & 18 & 0.72 & 19 & 0.86 & 21 & 0.67 & 21 \\
\hline
\end{tabular}

\section{RESUlts II: Compensating VARIATION AND Total WeLfare EFFECT}

The results in this section reveal the extent to which changes in the cost of living have differed between households over time and the contribution of price changes towards overall societal welfare. The Compensating Variation results show the change in the cost of living for different household groups for each year between 1999 and 2010. The total welfare effect is the effect of cost of living changes upon total societal welfare accounting for both private household welfare change and inequality aversion. The results show that the private welfare changes dominate the inequality effect in all years. This means that the sum of private household welfare changes does not depart far from the overall societal welfare change. Large differences between household groups are observed in some years thereby indicating that the Consumer Price Index is not always an accurate measure of the cost of living for different demographic groups and lends support to the case for a more disaggregated approach towards the reporting of price indices.

\section{Changes in Compensating Variation by Household Group}

The compensating variation measures the welfare change from changes in the cost of living for each household and is calculated using equation 1. Expressing the compensating variation as a percentage of total expenditure offers an approximation for the rate of increase or decline in the cost of living. The bottom row of table 6 gives the rate of change in the cost of living from 1999 to 2010. These differ from the Consumer Price Index 
reported by the CSO, because of some aggregation issues ${ }^{9}$, the adjustment for substitution bias and holding the budget survey constant. The results for each household group are the welfare impact of consumer price changes.

Table 5: Welfare Change from Consumer Price Changes $1999-2010^{10}$ by Household Group using the 2004/2005 Household Budget Survey

\begin{tabular}{|l|l|l|l|l|l|l|l|l|l|l|l|l|}
\hline & 1999 & 2000 & 2001 & 2002 & 2003 & 2004 & 2005 & 2006 & 2007 & 2008 & 2009 & 2010 \\
\hline 1 & -0.5 & 5.9 & 5.2 & 3.4 & 2.5 & 2.2 & 2.7 & 4.5 & 5.4 & 3.5 & -5.7 & -1.1 \\
\hline 2 & 2.7 & 5.7 & 3.9 & 4.4 & 3.5 & 1.9 & 2.0 & 2.3 & 2.4 & 3.4 & -1.8 & -1.7 \\
\hline 3 & 0.7 & 6.0 & 5.5 & 3.6 & 2.2 & 1.4 & 2.3 & 4.0 & 5.3 & 3.5 & -5.9 & -2.0 \\
\hline 4 & 1.7 & 5.5 & 4.7 & 4.1 & 2.9 & 1.4 & 1.7 & 2.9 & 3.9 & 3.3 & -3.4 & -2.4 \\
\hline 5 & -0.2 & 6.0 & 4.8 & 3.5 & 2.6 & 2.2 & 2.6 & 4.3 & 4.9 & 3.6 & -5.2 & -0.8 \\
\hline 6 & 2.8 & 5.6 & 3.7 & 4.7 & 3.7 & 2.0 & 2.0 & 2.2 & 2.2 & 3.3 & -1.3 & -1.4 \\
\hline 7 & -0.7 & 5.9 & 5.0 & 3.3 & 2.4 & 2.2 & 2.7 & 4.5 & 5.2 & 3.7 & -5.7 & -0.8 \\
\hline 8 & -0.6 & 5.7 & 5.0 & 3.3 & 2.3 & 2.1 & 2.5 & 4.4 & 5.1 & 3.7 & -5.6 & -0.9 \\
\hline 9 & 0.1 & 5.6 & 4.7 & 3.6 & 2.6 & 2.1 & 2.3 & 3.9 & 4.5 & 3.6 & -4.6 & -0.9 \\
\hline 10 & 2.8 & 4.9 & 4.4 & 4.0 & 3.2 & 1.4 & 1.2 & 2.1 & 3.0 & 4.3 & -0.9 & -3.0 \\
\hline 11 & 1.0 & 5.1 & 3.9 & 4.0 & 3.0 & 1.8 & 1.8 & 2.9 & 3.4 & 3.1 & -3.1 & -1.4 \\
\hline 12 & 1.9 & 5.4 & 3.7 & 4.4 & 3.4 & 2.0 & 2.0 & 2.7 & 3.0 & 2.9 & -2.4 & -1.4 \\
\hline Total & 0.7 & 5.6 & 4.4 & 3.9 & 2.9 & 2.1 & 2.3 & 3.5 & 4.1 & 3.3 & -4.0 & -1.2 \\
\hline
\end{tabular}

$1=$ single person, no children, under $652=$ one old person without children, $3=$ =single person with 1 child, $4=$ single parent with more than 2 children, $5=$ young couple without children, $6=$ couple without children and with at least one spouse more than $65,7=$ couple with one child, $8=$ couple with 2 children, $9=$ couple with 3 or more children, $10=$ family without children including person over $64,11=$ family where more children than 1 and number of adults more than $3,12=$ other

Note: Price Changes include Mortgage interest changes

The results show that there are considerable differences between household groups in terms of the welfare impact of price changes in 1999, 2006, 2007, 2009 and 2010 but less in other years. Beginning with 2009, the first year of deflation, the results show that households with a maximum of one child (groups 1, 3, 5, 7 and 8) benefitted from a fall of at least 5 per cent in the price level and thereby surpassing the average decline in the cost of living by at least 1.5 per cent. Single adults with one child (group 3) benefitted from a 5.9 per cent decline in the cost of living in 2009. The price index for both mortgage interest and rents fell dramatically in 2009 (Appendix Table A2). Those household groups with low budget shares for mortgage interest and rents benefitted from a much lower rate of deflation. Households including people over the age of 64 (2, 6 and 10) benefitted from deflation by less than 2 per cent.

The result for 2010 shows that price changes reduced the cost of living on average at a lower rate than in 2009. However some households departed from the average trend. Households including old people and more than one person (groups 6 and 10) experienced a larger drop in the cost of living in 2010 than in the case of 2009. This is partly due to higher than average budget shares for food and most heating expenditures which declined in price in 2010. Single adults with children experienced the highest deflation of all household groups in 2010 (groups 3 and 4). These households have high budget shares for

\footnotetext{
${ }^{9}$ The use of 21 aggregates means that large within-group price differentials are overlooked and not accounted for. The restaurant and hotel category does not include expenditures by tourists and is therefore lower than the share reported by the CSO for the CPI weights. We adjust the mortgage interest, alcohol and tobacco shares to be consistent with the CPI weights for the 2004/2005 budget survey but the same rescaling value is applied across the population and this may differ from the CSO method. We do the same for the alcohol and tobacco component in the restaurant and hotel expenditure category.

${ }^{10}$ 2004/2005 Household Budget Survey Anonymised microdata files
} 
rents and the price index for rents declined by 6 per cent in 2010. In addition, these households have above average shares for most home heating expenditures and food so that price declines for these most necessary expenditures favoured these households to a greater extent than other households.

In the first year of the budget survey itself (2004), the index for private rents declined by 4.2 per cent (Table A2). Household groups 3 and 4 (single people with children) benefitted from lower than average increase in the cost of living as a result. The mortgage interest index increased by 12.3 per cent in 2005 (Table A2). Household groups 1, 5 and 7 had a bigger increase in the cost of living than the average household largely due to this increase. There appears to have been large variation between household groups in 2006. Mortgage interest rose by 31.5 per cent and the same household groups as in 2009 lost welfare from much higher increases in the cost of living. This trend continued for 2007 as mortgage interest increased by 40.3 per cent. The large increase in food prices, local authority rents and mortgage interest in 2008 were not sufficient to produce large differentials in the cost of living between household groups.

Table 6. Welfare Change from Consumer Price Changes 1999-2010 ${ }^{11}$ by Household Group using the 1999/2000 Household Budget Survey

\begin{tabular}{|l|l|l|l|l|l|l|l|l|l|l|l|l|}
\hline Year & 1999 & 2000 & 2001 & 2002 & 2003 & 2004 & 2005 & 2006 & 2007 & 2008 & 2009 & 2010 \\
\hline 1 & 0.2 & 5.7 & 4.8 & 3.7 & 2.6 & 1.9 & 2.3 & 3.9 & 4.6 & 3.3 & -4.8 & -1.4 \\
\hline 2 & 2.7 & 5.4 & 4.0 & 4.5 & 3.5 & 1.8 & 1.9 & 2.4 & 2.5 & 3.7 & -1.5 & -1.9 \\
\hline 3 & -0.8 & 6.0 & 5.7 & 3.0 & 1.9 & 1.6 & 2.4 & 4.7 & 6.0 & 3.8 & -6.7 & -1.5 \\
\hline 4 & 1.1 & 5.3 & 5.0 & 3.9 & 2.9 & 1.5 & 1.7 & 3.1 & 4.3 & 3.8 & -3.6 & -2.5 \\
\hline 5 & 0.4 & 5.9 & 4.6 & 3.6 & 2.7 & 2.0 & 2.3 & 3.8 & 4.4 & 3.4 & -4.6 & -1.1 \\
\hline 6 & 2.6 & 5.4 & 3.5 & 4.4 & 3.4 & 1.9 & 1.8 & 2.2 & 2.2 & 3.4 & -1.8 & -1.6 \\
\hline 7 & -0.6 & 5.9 & 5.2 & 3.2 & 2.2 & 2.0 & 2.5 & 4.4 & 5.2 & 3.7 & -5.8 & -1.0 \\
\hline 8 & -0.7 & 5.7 & 5.2 & 3.2 & 2.2 & 2.0 & 2.4 & 4.4 & 5.1 & 3.8 & -5.8 & -1.0 \\
\hline 9 & 0.0 & 5.5 & 4.9 & 3.4 & 2.3 & 1.8 & 2.1 & 3.9 & 4.6 & 3.7 & -4.9 & -1.3 \\
\hline 10 & 1.9 & 4.8 & 3.4 & 3.0 & 2.1 & 1.0 & 1.5 & 1.8 & 1.8 & 3.5 & -3.5 & -2.1 \\
\hline 11 & 1.4 & 5.2 & 4.0 & 3.9 & 3.1 & 1.8 & 1.6 & 2.7 & 3.3 & 3.2 & -2.9 & -1.8 \\
\hline 12 & 2.0 & 5.3 & 3.8 & 4.3 & 3.4 & 1.9 & 1.8 & 2.6 & 2.9 & 2.9 & -2.3 & -1.7 \\
\hline Total & 0.9 & 5.5 & 4.4 & 3.8 & 2.9 & 1.9 & 2.0 & 3.3 & 3.8 & 3.3 & -3.8 & -1.4 \\
\hline
\end{tabular}

$1=$ single person, no children, under $65,2=$ one old person without children, $3=$ =single person with 1 child, $4=$ single parent with more than 2 children, $5=$ =young couple without children, $6=$ couple without children and with at least one spouse more than $65,7=$ couple with one child, $8=$ couple with 2 children, $9=$ couple with 3 or more children, $10=$ family without children including person over $64,11=$ family where more children than 1 and number of adults more than $3,12=$ other

It is best to analyse the trend for 1999 to 2003 using the 1999/2000 household budget survey. A brief comparison of table 5 and table 6 will show that the average change in the cost of living does not differ much whether one uses the 1999/2000 budget survey or the 2004/2005 survey. There are however some differences within household groups. In the first year under study (1999), the large decline in the mortgage interest price index benefitted many households with young adults i.e. groups 1, 7 and 8 because of high budget shares in mortgage interest. Single adults with children (group 3) experienced the greatest deflation of 0.8 per cent as the low budget share for healthcare expenditures meant that such households did not lose as much from the healthcare price increase.

The rise in the cost of living peaked at 5.5 per cent in the following year but there appears to have been little difference between household groups. The large increase in food prices

11 1999/2000 Household Budget Survey Anonymised microdata files 
of 6.5 per cent in 2001 (Table A2) was overshadowed by the even larger increase in the index for mortgage interest (24.8), local authority rents (13.7), private rents (14.6) and refuse collection (26.8). This meant that household groups with the highest food shares did not have the biggest increases in the cost of living. In this year, the greatest increase in the cost of living was experienced by single adults with children (group 3) and therefore reversing the trend of the previous year.

Households including old people only experienced the highest increase in the cost of living in 2002 compared to other household groups. This was due to the large increase in healthcare costs of 10 per cent. The same adverse trend for older people continued in 2003 as such households continued to lose from high healthcare spending while not benefitting directly from cost reductions in clothing, rents and mortgage interest to the same extent as other household groups.

Table 7: Welfare Loss of Consumer Price Changes including Mortgage Interest Repayments 1999-2010 ${ }^{12}$ by Decile of Equivalised Total Expenditure

\begin{tabular}{|c|c|c|c|c|c|c|c|c|c|c|c|c|}
\hline & \multicolumn{12}{|c|}{ 1999/2000 Household Budget Survey } \\
\hline & 1999 & 2000 & 2001 & 2002 & 2003 & 2004 & 2005 & 2006 & 2007 & 2008 & 2009 & 2010 \\
\hline Poorest & 2.1 & 4.9 & 4.6 & 4.0 & 3.0 & 1.5 & 1.7 & 2.5 & 3.4 & 4.9 & -2.4 & $\begin{array}{l}-2.2 \\
\end{array}$ \\
\hline 2 & 2.0 & 5.1 & 4.4 & 4.0 & 3.0 & 1.6 & 1.7 & 2.6 & 3.4 & 4.4 & -2.6 & -2.0 \\
\hline 3 & 1.6 & 5.3 & 4.4 & 3.9 & 2.9 & 1.7 & 1.8 & 2.8 & 3.6 & 4.1 & -3.0 & \begin{tabular}{|l|l}
-1.8 \\
\end{tabular} \\
\hline 4 & 1.4 & 5.5 & 4.4 & 3.9 & 2.9 & 1.8 & 1.9 & 3.1 & 3.8 & 4.0 & $\begin{array}{l}-3.3 \\
\end{array}$ & -1.6 \\
\hline 5 & 1.4 & 5.5 & 4.3 & 3.9 & 3.0 & 1.8 & 2.0 & 3.1 & 3.7 & 3.8 & -3.3 & -1.5 \\
\hline 6 & 1.2 & 5.7 & 4.4 & 3.9 & 3.0 & 1.9 & 2.1 & 3.3 & 3.9 & 3.6 & -3.6 & -1.4 \\
\hline 7 & 0.9 & 5.8 & 4.5 & 3.9 & 2.9 & 2.0 & 2.2 & 3.5 & 4.0 & 3.6 & -3.8 & $\begin{array}{l}-1.3 \\
\end{array}$ \\
\hline 8 & 0.6 & 5.9 & 4.6 & 3.8 & 2.8 & 2.1 & 2.3 & 3.8 & 4.3 & 3.5 & -4.4 & -1.1 \\
\hline 9 & 0.6 & 6.0 & 4.6 & 3.8 & 2.9 & 2.2 & 2.4 & 3.9 & 4.3 & 3.4 & -4.4 & -1.1 \\
\hline Richest & 0.5 & 6.2 & 4.7 & 3.8 & 2.8 & 2.1 & 2.4 & 4.0 & 4.4 & 3.3 & -4.8 & -1.1 \\
\hline \multirow[t]{3}{*}{ Total } & 0.9 & 5.8 & 4.5 & 3.9 & 2.9 & 2.0 & 2.2 & 3.5 & 4.1 & 3.6 & -4.0 & -1.3 \\
\hline & \multicolumn{12}{|c|}{ 2004/2005 Household Budget Survey } \\
\hline & 1999 & 2000 & 2001 & 2002 & 2003 & 2004 & 2005 & 2006 & 2007 & 2008 & 2009 & 2010 \\
\hline Poorest & 2.3 & 5.4 & 4.2 & 4.2 & 3.4 & 1.9 & 2.3 & 2.6 & 3.3 & 4.6 & -2.4 & $\begin{array}{l}-1.7 \\
\end{array}$ \\
\hline 2 & 2.0 & 5.4 & 4.1 & 4.2 & 3.3 & 1.9 & 2.2 & 2.6 & 3.3 & 4.1 & -2.6 & -1.6 \\
\hline 3 & 1.7 & 5.6 & 4.2 & 4.1 & 3.2 & 1.9 & 2.2 & 2.9 & 3.6 & 3.9 & -3.0 & -1.5 \\
\hline 4 & 1.4 & 5.6 & 4.3 & 4.0 & 3.1 & 2.0 & 2.2 & 3.1 & 3.7 & 3.7 & -3.3 & -1.4 \\
\hline 5 & 1.3 & 5.7 & 4.3 & 4.0 & 3.1 & 2.1 & 2.3 & 3.2 & 3.8 & 3.6 & -3.4 & -1.3 \\
\hline 6 & 0.8 & 5.8 & 4.4 & 3.9 & 3.0 & 2.1 & 2.4 & 3.6 & 4.1 & 3.6 & -3.9 & -1.1 \\
\hline 7 & 0.7 & 5.8 & 4.5 & 3.9 & 2.9 & 2.1 & 2.4 & 3.7 & 4.2 & 3.5 & -4.1 & -1.1 \\
\hline 8 & 0.5 & 6.0 & 4.5 & 3.8 & 2.9 & 2.2 & 2.5 & 3.8 & 4.4 & 3.5 & -4.4 & -1.0 \\
\hline 9 & 0.6 & 6.2 & 4.6 & 3.9 & 3.0 & 2.3 & 2.6 & 4.0 & 4.5 & 3.5 & -4.5 & -0.9 \\
\hline Richest & -0.3 & 6.3 & 5.0 & 3.7 & 2.6 & 2.4 & 2.7 & 4.6 & 5.1 & 3.5 & -5.6 & -0.7 \\
\hline Total & 0.7 & 5.9 & 4.5 & 3.9 & 2.9 & 2.2 & 2.5 & 3.7 & 4.3 & 3.6 & -4.2 & -1.1 \\
\hline
\end{tabular}

The differential change in the cost of living between households appears just as strong in the case of households at different points of the income distribution as between households with different demographic characteristics.

Taking the 2004/2005 budget survey as a base, one can see that 2006 to 2010, the gap in the cost of living change in each year was 1.1 per cent or greater between the top and bottom 
decile. This difference is over 1.5 per cent in 2006, 2007 and 2009. In 2006, there was a 2 per cent gap between the top and bottom decile largely driven by mortgage interest repayments. A similar trend occurred in 2007. The large increase in food prices in 2008 manifested itself in higher increases for those in the bottom two deciles. In 2009, the gap between those at the bottom and the top was 3.2 per cent using the 2004/2005 budget survey as a base. Households at the bottom of the distribution benefitted from deflation of around 2.5 per cent while those at the top benefitted from deflation of on or above 4.5 per cent. The 2010 results show that households in the bottom of the distribution benefitted from falling prices to a greater extent than households at the top of the distribution. This is driven by declining food prices and home heating costs.

Taking the 1999/2000 budget survey data as a base, one can see that price changes caused a 0.5 per cent increase in the cost of living while the bottom decile experienced an increase of 2.1 per cent in the cost of living. This was partially reversed the following year as households higher in the distribution experienced higher increases. Murphy and Garvey (2004) identified a large effect of price changes upon inequality between 1996 and 2001. There is some overlap with that study. We find that price changes increased inequality in 1999 but not 2000 and 2001 and that the 1999 inequality increase is likely to dominate the inequality reducing effect in 2000.

\section{Decomposing Welfare Changes}

The results from Tables 8-9 show that the private welfare changes from consumer prices far outweigh the inequality component in terms of their impact upon overall welfare. However the extent of this result depends on the value of the inequality aversion parameter. An inequality aversion parameter of 0.3 gives greater weight to the private household losses than to the inequality component (Table 9). A higher inequality aversion parameter of say 0.8 gives greater weight to the private household losses than to the inequality component but to a lesser extent. This means that the extent to which policies redistribute income on the basis of differential price changes must find justification from the degree of inequality aversion in society. We use an inequality aversion value of 0.3 due to the results of (Amiel et.al, 1999).

Table 8 shows that the original $y_{\text {ede }}$ i.e. the equally distributed level of equivalent income is 706.67 euro. This means that the average total household expenditure accounting for inequality aversion is 706.67 euro. The absence of inequality aversion and price changes would mean that $y_{\text {ede }}$ simply equates to the average total household expenditure of 791 euro. In table 8, the $y_{\text {ede }}$ post price change was 700.23 in 1999. Most of the decline in $y_{\text {ede }}$ post price change was due to private household losses (87.7 per cent). However the change in the Atkinson inequality index accounted for 12.3 per cent of the decline in $y_{\text {ede }}$. The contribution of inequality change is much less in subsequent years. The results of table 7 support this result. In 2009, we find that $y_{\text {ede }}$ increases by 3.3 per cent because of the change in the inequality index. In 2010, it is reduced by 3.3 per cent because of the change in the inequality index. 
TABle 7: CONTRIBUTION OF PRIVATE WELFARE AND INEQUALITY CHANGE ON LEVEL OF EQUALLY DisTRIBUTED EQUIVALENT INCOME

\begin{tabular}{|c|c|c|c|c|c|}
\hline & Original $\mathrm{Y}_{\text {ede }}$ & $Y_{\text {ede }}$ Post Price Changes & Percentage Change in $\mathrm{Y}_{\text {ede }}$ & Percentage due to Private Welfare Change & Percentage due to Inequality \\
\hline 1999 & 706.67 & 700.23 & $\begin{array}{c}-0.9 \\
\end{array}$ & 87.7 & \begin{tabular}{|l|}
12.3 \\
\end{tabular} \\
\hline 2000 & $\begin{array}{l}706.67 \\
\end{array}$ & 664.78 & -5.9 & 100.3 & -0.3 \\
\hline 2001 & 706.67 & 674.42 & -4.6 & 100.1 & $\begin{array}{l}-0.1 \\
\end{array}$ \\
\hline 2002 & 706.67 & 678.71 & -4.0 & 99.6 & 0.4 \\
\hline 2003 & 706.67 & 685.31 & -3.0 & 99.0 & 1.0 \\
\hline 2004 & 706.67 & 691.43 & -2.2 & 100.9 & -0.9 \\
\hline 2005 & 706.67 & 689.20 & -2.5 & 100.2 & -0.2 \\
\hline 2006 & 706.67 & 680.79 & -3.7 & 101.6 & -1.6 \\
\hline 2007 & 706.67 & 676.73 & -4.2 & 100.9 & -0.9 \\
\hline 2008 & $\begin{array}{l}706.67 \\
\end{array}$ & 680.85 & -3.7 & 98.3 & \begin{tabular}{|l|}
1.7 \\
\end{tabular} \\
\hline 2009 & 706.67 & 734.97 & 4.0 & 103.3 & \begin{tabular}{|l|}
-3.3 \\
\end{tabular} \\
\hline 2010 & 706.67 & 714.63 & 1.1 & 96.7 & 3.3 \\
\hline
\end{tabular}

\section{TABle 8: Contribution Of Private Welfare Change AND INEQUality Change ON OVERALL WeLFARE (W)}

\begin{tabular}{|c|c|c|c|c|c|}
\hline & Original W & Welfare Post Price Changes & Percentage Change in Welfare & Percentage due to Private Welfare Change & Percentage due to Inequality \\
\hline 1999 & 141.04 & 140.14 & -0.6 & 87.7 & 12.3 \\
\hline 2000 & 141.04 & 135.14 & -4.2 & 100.3 & -0.3 \\
\hline 2001 & 141.04 & 136.51 & -3.2 & 100.1 & -0.1 \\
\hline 2002 & 141.04 & 137.11 & -2.8 & 99.6 & 0.4 \\
\hline 2003 & 141.04 & 138.05 & -2.1 & 99.0 & 1.0 \\
\hline 2004 & 141.04 & 138.91 & -1.5 & 100.9 & -0.9 \\
\hline 2005 & 141.04 & 138.59 & -1.7 & 100.2 & -0.2 \\
\hline 2006 & 141.04 & 137.41 & -2.6 & 101.7 & -1.7 \\
\hline 2007 & 141.04 & 136.83 & -3.0 & 100.9 & -0.9 \\
\hline 2008 & 141.04 & 137.42 & -2.6 & 98.3 & 1.7 \\
\hline 2009 & 141.04 & 144.97 & 2.8 & 103.3 & -3.3 \\
\hline 2010 & 141.04 & 142.15 & 0.8 & 96.7 & 3.3 \\
\hline
\end{tabular}


The welfare results in Table 9 follow the same pattern as those in Table 8 which is not surprising given that welfare is derived from the $y_{\text {ede }}$ value (Equation 14). The added value of the welfare measure over $y_{\text {ede }}$ is that the welfare measure accelerates in response to a change in the rate of change in the cost of living. As the rate of change in the cost of living increases, it has an accelerating affect on the welfare measure. This makes theoretical sense. As the increase in the cost of living becomes greater, the value that is placed upon each additional unit of lost consumption increases. That is because the last unit of consumption lost will tend to have a greater value than the first unit lost i.e. diminishing marginal utility and the ranking of goods.

In some cases the private household welfare change and the inequality change work in opposite directions. The private welfare change component can therefore exceed 100 per cent.

\section{CONCLUSION}

The cost of living is a primary concern for households in Ireland today especially given the background of declining nominal household incomes and wider macroeconomic difficulties. This paper has provided a single overall welfare measure to analyse the contribution of price changes towards household welfare in Ireland between 1999 and 2010. This welfare measure has been decomposed into efficiency and equity components. The efficiency component is a Cost of Living Index that accounts for the behavioural response of consumers to price changes for non-essential expenditures. No substitution behaviour is assumed to take place among a calculated level of subsistence expenditures. The equity component is the Atkinson Inequality Index which can change in value as price changes affect the real standard of living for households in different parts of the income distribution. The results clearly show that the efficiency components dominate the equity component in all years in terms of their relative impact upon overall welfare.

The low contribution of the equity component is perhaps not surprising given that the average change in the cost of living exceeded 2.5 per cent in 8 of the 12 years studied. Households are likely to prioritise their own welfare to a greater extent than their concern for inequality so that changes in the cost of living are likely to outweigh the inequality effects. The equity component could potentially dominate the efficiency component if there is very low movement in the overall price level combined with large shifts in relative prices. This describes to some extent the situation in 1999 as the overall price level shifted by approximately one per cent and large relative price movements produced large differential changes in the cost of living between households at different points in the income distribution. In that year, the decline in welfare was 12.3 per cent due to the change in inequality according to our calculations.

Large shifts in relative prices are evident in many years. Much of this is due to the volatility in the cost of mortgage interest which changed by more than 10 per cent in 8 of the 12 years concerned. There are long run shifts in relative prices between commodity groups over the entire period as some commodity price indices increased uninterrupted over time while the price index for other commodity groups declined uninterrupted over time. This is evident from the long run upward movement in the price index for health, education, local 
authority rents, refuse collection and solid fuels and the long downward trend in clothing and footwear, furniture and household equipment over the period.

These large relative price shifts have generated substantial differences in the change in the cost of living between households in most years. This means that concentrating on the cost of living change for the average household can disguise important information about the extent of the change for many households. The results indicate that there is no clear relationship between the percentage change in the cost of living and the position of households in the income distribution or the demographic composition of the household over the entire period. This is despite the large variation in consumption baskets between households in different parts of the income distribution and between households with different demographic composition.

The inclusion of the behavioural response component in the cost of living calculation is an acknowledgement that the CPI can be potentially biased for excluding substitution behaviour. We find that the substitution bias is greater than the findings of Sommerville (2004) albeit using a different demand system and time period. The substitution bias is best calculated using a base price index that is relatively close to that of the reform price. It is unrealistic to assume that consumers make their behavioural response decisions with reference to a base price index of at least 4 to 5 years previous. Consumers could potentially alter their consumption baskets from one good to another and back again over long periods. The use of a very old base price index as a base price index could potentially hide this back and forth substitution.

Our results show that the substitution bias per annum between 1999 and 2002 is 0.15 using the 1998 price index as the base. Employing an objective measure of subsistence expenditure can alter the results ${ }^{13}$. This method produces a substitution bias of 0.08 between 1999 and 2002. Using the 2006 price index as a base produces an average bias of 0.18 between 2007 and 2010 but there is considerable variation in this period. There are two years of deflation in 2009 and 2010 and the deflation of 2009 substantially reduces the calculated gap between Cost of Living Index and the Laspeyres Price Index. This narrowing of the gap between these indices can occur in the case of deflation that is preceeded by years of inflation. Substitution behaviour in 2010 is unlikely to be made by consumers with reference to 2006 prices so that the average bias of 0.18 is probably a lower bound on the extent of the substitution bias for the period of 2007 to 2010. The average bias is 0.22 using the objective measure of subsistence.

With regard to a movement towards a Cost of Living Index, we arrive at a similar conclusion to Murphy and Garvey (2008). The complexity of substitution bias measurement and the sensitivity of the results to the choice of subsistence expenditure, base price index, demand system and choice of independent variables in the budget regressions and other factors should caution policymakers about adopting such a system. The use of a Hicksian compensating demand system is only advisable if there is a realistic potential for

\footnotetext{
${ }^{13}$ The objective measure of subsistence assumes that all food, clothing, communications, rents, mortgage interest, refuse collection and home heating are subsistence expenditures and that no part of other commodities are categorised as subsistence. In addition, we assume that the marginal budget shares for these subsistence expenditures are zero. The results show that the bias is sensitive to such an objective measure of subsistence. However the assumption that no fraction of supposedly non-essential goods is essential means that the results should not be taken as a completely accurate representation of reality.
} 
income compensation to take place. It is otherwise unethical to proceed with such a measure. The likelihood of compensation is increasingly unlikely for many households in Ireland given the scale of unemployment and indebtedness. A fall in real wages via higher prices could ceteris paribus, be viewed by policymakers as a path towards reducing unemployment. Substitution behaviour will continue to take place but the prospects of income compensation for price changes is most likely in decline. Therefore uncompensated measures of utility may be more appropriate in the near future.

The relative simplicity of the Laspeyres Price Index means that a larger number of economic agents can more easily use the index as a measurement of change in the cost of living. The addition of a behavioural bias could add too much complexity for many economic agents. The signalling benefits of a relative simple price index in comparison to the Cost of Living Index are clearly difficult if not impossible to quantify but remain crucial to the everyday workings of the economic system. Another clear ethical issue is that miscalculating the substitution bias could potentially harm people that are displaying substitution behaviour i.e. over-estimating the substitution bias and therefore reducing the cost of living index to a greater extent than is true.

The Cost of Living issue holds an important position in the wider macroeconomic debate. There has been broad support in recent times for a more expansionary monetary policy but one that does not have too many onerous conditions attached. The CPI increased by 3.2 per cent between April 2010 and April 2011 (1.9 per cent excluding mortgage interest). This trend has the capacity to reduce the broad support for a more expansionary monetary policy. It is worth reminding however that the principle concern about inflation is the potential distortionary impact that it can have on the real economy. Should monetary policy affect all incomes in the same proportion and no reallocation of resources occurs due to policy, then money can be viewed as neutral towards the real economy. Targeting the growth in overall price level is the chosen method by monetary policymakers to protect the credibility of the currency and thereby bring money closer to neutrality. There still remains considerable room for distortionary impacts to occur with this target in a large monetary union such as EMU.

Putting monetary policy to one side, there are clearly diverging opinions about the desirability or otherwise of further declines in the overall price level. For domestic solutions, some point to the necessity of targeted efforts to reduce prices in protected or sheltered sectors of the economy. This could potentially manifest itself in declines in the overall price level and improvements for household welfare. The objections to these measures are that a narrow set of accounts will be badly affected. This protest is rarely complemented by an adequate recognition of the economic implications for a wider set of accounts i.e. consumers and new entrant business. The omission of these domino effects can potentially lead to the exit or non-entry of business to and from the marketplace and the continued idleness of labour resources from Irish households as well as the non-realisation of welfare improvements for households through lower prices.

The argument that price controls can support aggregate demand in the current crisis must not go unchallenged. This argument clearly ignores that a primary motivation of Keynesian economics is pessimism regarding the flexibility of prices. The support for price controls does not in itself offer a solution towards improving welfare for all households but may well benefit a subset of households. It only serves to remind policymakers of the real 
difficulties of attempting to engineer improvements in household welfare in the context of a rapidly shrinking money supply and aggregate demand. The findings in this paper can be complemented by a reading of Whelan and Maitre (2010) which clearly shows that many of 'the economically vulnerable' earn incomes above the 60 per cent relative poverty line. This should be taken into account as targeted policy efforts to compensate for increases in the cost of living should not be based solely on the position of the household in the income distribution or their demographic composition but also on levels of deprivation and vulnerability as shown by Whelan and Maitre. 


\section{APPENDIX I. CRITERIA FOR 12 DEMOGRAPHIC GROUPS}

Group 1 - There is only one person in the household and none of the individuals are aged 65 or over. The vast majority (approx. 85\%) of these individuals are never-married, widowed or divorced. There are some cases of individuals that are married but not residing with their spouse on a permanent basis (approx. 15\%).

Group 2 - There is only one person in the household and none of these individuals are 65 or over. The majority of people in this group are widows or widowers (approx. 65\%). The remainder include single people that have never married (approx. 30\%) and a small minority that are divorced or married but not residing with their spouse on a permanent basis.

Group 3 - There is only one adult and one child in the household. The vast majority of the adults in this household have never married (approx. 90\%). A small minority of the adults are divorce, widowed or married but not residing with their spouse on a permanent basis.

Group 4 - There is only one adult and there are at least two children in the household. Approximately half of these households are headed by adults that have never married and approximately 40 per cent are headed by married people living not residing with their spouse on a permanent basis. About one in ten are headed somebody that is divorced or widowed.

Group 5 - These households include married couples living together on a permanent basis with no children in the household. Therefore all of these households have two adults residing in them.

Group 6 - These households include couples living together on a permanent basis with no children in the household. At least one of the adults is aged 65 or over. All of these households have two adults residing in them.

Group 7 - These households include couples living together on a permanent basis with one child in the household.

Group 8 - These households include couples living together on a permanent basis with two children in the household.

Group 9 - These households include couples living together on a permanent basis with three children or more in the household.

Group 10 - All individuals in these households are aged 65 or older. There are more than two people living in these households. The vast majority are headed by people in a married relationship aged 65 and over (approx. 80\%) and the remainder are mainly either widowed or never married.

Group 11 - These are households with more than three people and at least one of the household members is a child. The vast majority are headed by people in a married 
relationship living together on a permanent basis (approx. 90\%) and the remainder are single, widowed, divorced or never married.

Group 12 - Any household that does not qualify under the criteria for the first eleven household groups enters this category. About 22 per cent of all households in the survey fall into this category. This large percentage is due to a number of factors. Approximately half of these households are headed by unmarried adults living together but not considered to be spouses to one another. Approximately half of the households in this category are headed by people in married relationships living together on a permanent basis. All of these households have a minimum of three adults in the household and none of these households includes more than one child.

\section{APPENDiX II: DATA}

Table A1: Independent Variables for Budget Share Regressions

\begin{tabular}{|l|l|l|l|}
\hline Consumption and Employment Variables & Age and Education Variables & Household Size Variables & Household Tenure Variables \\
\hline Log of Total Consumption & Co_age1 (Age-40)/10 & Number of children aged 0-5 years old & Mortgage Holder \\
\hline Log of Total Consumption Squared & $\begin{array}{l}\text { Co_age2 (Co_age1 } \\
\text { Squared) }\end{array}$ & Number of children aged 5-13 years old & Outright Owner \\
\hline Smoker & Co_age3 (Co_age2 squared) & Number of children aged 14-20 years old & Tenant Purchaser \\
\hline Car owner & Upper Secondary Education & Number of people over 65 years old & Local Authority Tennant \\
\hline Employee & University Education & Number of Adults aged 21 and over & Private Tenant \\
\hline Self-Employed & Married & Number of Bedrooms & Rent Free \\
\hline Other Employment & Gender of Household Head & & $\begin{array}{l}\text { Less than ten years resident in the } \\
\text { household (0,1) }\end{array}$ \\
\hline Number of earners & Pension & & \\
\hline
\end{tabular}


Table A2. Price Inflation for Twenty-One Commodity Groups 1999-2010

\begin{tabular}{|c|c|c|c|c|c|c|c|c|c|c|c|c|c|}
\hline $\begin{array}{l}\text { Commodity } \\
\text { Group }\end{array}$ & 1999 & 2000 & 2001 & 2002 & 2003 & 2004 & 2005 & 2006 & 2007 & 2008 & 2009 & 2010 & Total \\
\hline $\begin{array}{l}\text { Food and Non- } \\
\text { Alcoholic } \\
\text { Beverages }\end{array}$ & 3.1 & 3.1 & 6.5 & 3.5 & 1.4 & -0.3 & -0.7 & 1.4 & 2.9 & 6.5 & -3.4 & -4.5 & 20.3 \\
\hline $\begin{array}{l}\text { Alcoholic } \\
\text { Beverages, } \\
\text { Tobacco }\end{array}$ & 4.0 & 11.5 & 2.5 & 5.6 & 9.8 & 3.5 & 0.6 & 1.1 & 5.4 & 4.7 & 6.3 & -2.6 & 66.0 \\
\hline $\begin{array}{l}\text { Clothing and } \\
\text { Footwear }\end{array}$ & $\begin{array}{l}-6.3 \\
\end{array}$ & -4.9 & -2.8 & $\begin{array}{l}-4.3 \\
\end{array}$ & -4.0 & -3.5 & -2.8 & -2.0 & -3.2 & -4.9 & -11.8 & $\begin{array}{l}-9.4 \\
\end{array}$ & -46.1 \\
\hline $\begin{array}{l}\text { Furnishings, } \\
\text { Household } \\
\text { Equipment and } \\
\text { Routine } \\
\text { Maintenance of } \\
\text { the House }\end{array}$ & 2.4 & 4.5 & 3.5 & 1.7 & -0.7 & -1.8 & -1.4 & -1.3 & -1.8 & -1.5 & -3.2 & -4.1 & -3.9 \\
\hline Health & 5.7 & 7.1 & 7.5 & 10.0 & 7.7 & 6.0 & 6.2 & 4.4 & 3.0 & 5.9 & 3.6 & 0.6 & 92.5 \\
\hline Transport & 2.3 & 8.0 & -1.6 & 3.0 & 3.3 & 4.1 & 3.5 & 3.4 & 2.1 & 3.4 & -3.9 & 3.1 & 34.8 \\
\hline Communication & -7.4 & -3.0 & -8.3 & 2.1 & 1.5 & 2.7 & -0.2 & -0.5 & 0.5 & 1.0 & 0.5 & 1.4 & -9.9 \\
\hline $\begin{array}{l}\text { Recreation and } \\
\text { Culture }\end{array}$ & 2.9 & 3.7 & 4.9 & 6.3 & 4.1 & 1.2 & 0.0 & 1.3 & 1.5 & 1.3 & -0.4 & -1.8 & 27.9 \\
\hline Education & 10.3 & 10.6 & 7.2 & 10.3 & 9.1 & 5.8 & 6.0 & 4.9 & 5.1 & 6.1 & 6.4 & 6.4 & 133.2 \\
\hline $\begin{array}{l}\text { Restaurants and } \\
\text { Hotels }\end{array}$ & 4.1 & 5.5 & 6.0 & 7.4 & 6.3 & 4.0 & 3.3 & 3.9 & 4.2 & 3.1 & 0.0 & -2.6 & 55.0 \\
\hline $\begin{array}{l}\text { Miscellaneous } \\
\text { Goods and } \\
\text { Services }\end{array}$ & 5.6 & 7.6 & 9.3 & 9.7 & 4.7 & -0.6 & -0.1 & 1.6 & 1.0 & 2.3 & 7.6 & 1.1 & 61.9 \\
\hline $\begin{array}{l}\text { Local Authority } \\
\text { Rents }\end{array}$ & 7.4 & 12.2 & 13.7 & 19.2 & 15.1 & 7.9 & 7.7 & 8.0 & 9.0 & 19.6 & 5.4 & -2.1 & 217.5 \\
\hline Private Rents & 5.9 & 10.4 & 14.6 & 2.8 & -3.4 & -4.2 & 0.7 & 5.3 & 11.0 & 2.7 & -17.4 & -6.0 & 19.7 \\
\hline $\begin{array}{l}\text { Mortgage } \\
\text { Interest }\end{array}$ & -27.6 & 12.3 & 24.8 & -7.7 & -8.1 & 5.4 & 12.3 & 31.5 & 40.3 & 15.0 & -40 & 6.4 & 37.8 \\
\hline $\begin{array}{l}\text { Materials for } \\
\text { maint. \& repair } \\
\text { of dwelling }\end{array}$ & 2.8 & 3.7 & 4.0 & 2.3 & 1.5 & 0.8 & 3.1 & 3.0 & 3.4 & 1.2 & -1.2 & -2.1 & 26.5 \\
\hline $\begin{array}{l}\text { Serv. for maint. } \\
\text { \& repair of } \\
\text { dwelling }\end{array}$ & 2.8 & 3.7 & 4.0 & 6.9 & 6.7 & 5.1 & 2.8 & 4.3 & 5.1 & 3.6 & -1.6 & -4.5 & 45.8 \\
\hline $\begin{array}{l}\text { Refuse } \\
\text { Collection }\end{array}$ & 30.8 & 25.5 & 26.8 & 19.2 & 22.4 & 19.6 & 30.2 & 6.8 & 4.5 & 0.6 & 0.0 & -2.8 & 416.2 \\
\hline Electricity & 0.0 & 0.0 & 0.3 & 8.8 & 10.8 & 7.1 & 13.2 & 4.2 & 11.6 & 2.4 & 1.3 & -3.5 & 70.5 \\
\hline Natural Gas & 0.0 & 0.0 & 0.0 & 0.0 & 5.7 & 5.0 & 16.8 & 27.9 & 9.6 & -1.0 & 1.8 & -13.5 & 58.5 \\
\hline Liquid fuels & 6.5 & 48.8 & -1.5 & -8.4 & 3.5 & 11.9 & 27.7 & 10.4 & -1.4 & 27.2 & -32.4 & 31.5 & 160.2 \\
\hline Solid fuels & 2.7 & 5.4 & 8.1 & 4.1 & 2.9 & 3.6 & 7.6 & 7.6 & 8.7 & 9.2 & 7.6 & -2.5 & 87.1 \\
\hline$C P I$ & 1.60 & 5.60 & 4.90 & 4.60 & 3.50 & 2.20 & 2.50 & 4.00 & 4.90 & 4.10 & -4.5 & $\begin{array}{l}-1.0 \\
\end{array}$ & 36.9 \\
\hline
\end{tabular}


Appendix III: Substitution Bias in The LAspeyres Price IndeX

Table A3. The Measured Substitution Bias in the Consumer Price Index 1999-2010

\begin{tabular}{|c|c|c|c|c|c|c|c|c|c|c|c|c|}
\hline Year & 1999 & 2000 & 2001 & 2002 & 2003 & 2004 & 2005 & 2006 & 2007 & 2008 & 2009 & 2010 \\
\hline $\begin{array}{l}\text { Cumulative Bias } 1998 \\
\text { Price Index Base using } \\
\text { LES Demand System }^{14}\end{array}$ & 0.12 & 0.21 & 0.38 & 0.59 & 0.94 & 1.14 & 1.47 & 1.75 & 2.45 & 3.18 & 3.10 & 3.57 \\
\hline $\begin{array}{l}\text { Cumulative Bias } 1998 \\
\text { Price Index Base using } \\
\text { LES Demand System but } \\
\text { under Objective } \\
\text { Subsistence Measure }\end{array}$ & 0.05 & 0.05 & 0.18 & 0.31 & 0.48 & 0.52 & 0.56 & 0.61 & 0.74 & 0.89 & 1.33 & 1.41 \\
\hline $\begin{array}{l}\text { Average Bias } 1998 \text { Price } \\
\text { Index Base using LES } \\
\text { Demand System }\end{array}$ & 0.12 & 0.11 & 0.13 & 0.15 & 0.19 & 0.19 & 0.21 & 0.22 & 0.27 & 0.32 & 0.28 & 0.30 \\
\hline $\begin{array}{l}\text { Average Bias } 1998 \text { Price } \\
\text { Index Base using LES } \\
\text { Demand System but } \\
\text { under Objective } \\
\text { Subsistence Measure } \\
\end{array}$ & 0.05 & 0.03 & 0.06 & 0.08 & 0.10 & 0.09 & 0.08 & 0.08 & 0.08 & 0.09 & 0.12 & 0.12 \\
\hline $\begin{array}{l}\text { Average Bias } 2006 \text { Price } \\
\text { Index Base using LES } \\
\text { Demand System }\end{array}$ & - & - & - & - & - & - & - & - & 0.46 & 0.46 & 0.15 & 0.18 \\
\hline $\begin{array}{l}\text { Average Bias } 2006 \text { Price } \\
\text { Index Base using LES } \\
\text { Demand System but } \\
\text { under Objective } \\
\text { Subsistence Measure }\end{array}$ & - & - & - & - & - & - & - & - & 0.12 & 0.16 & 0.18 & 0.22 \\
\hline
\end{tabular}

${ }^{14}$ This is calculated as $((\mathrm{Lt}-\mathrm{Ct}) / \mathrm{Ct}) * 100$. Lt represents the Laspeyres Price Index and Ct represents the Cost of Living Index. The former does not include the substitution behaviour whereas the latter index does account for substitution bias. This measure is the usual summary statistic for the calculation of this bias (Sommerville (2004). 
Table A.4a: Regression Outputs from 2004 Household Budget Survey $\operatorname{data}^{15}$

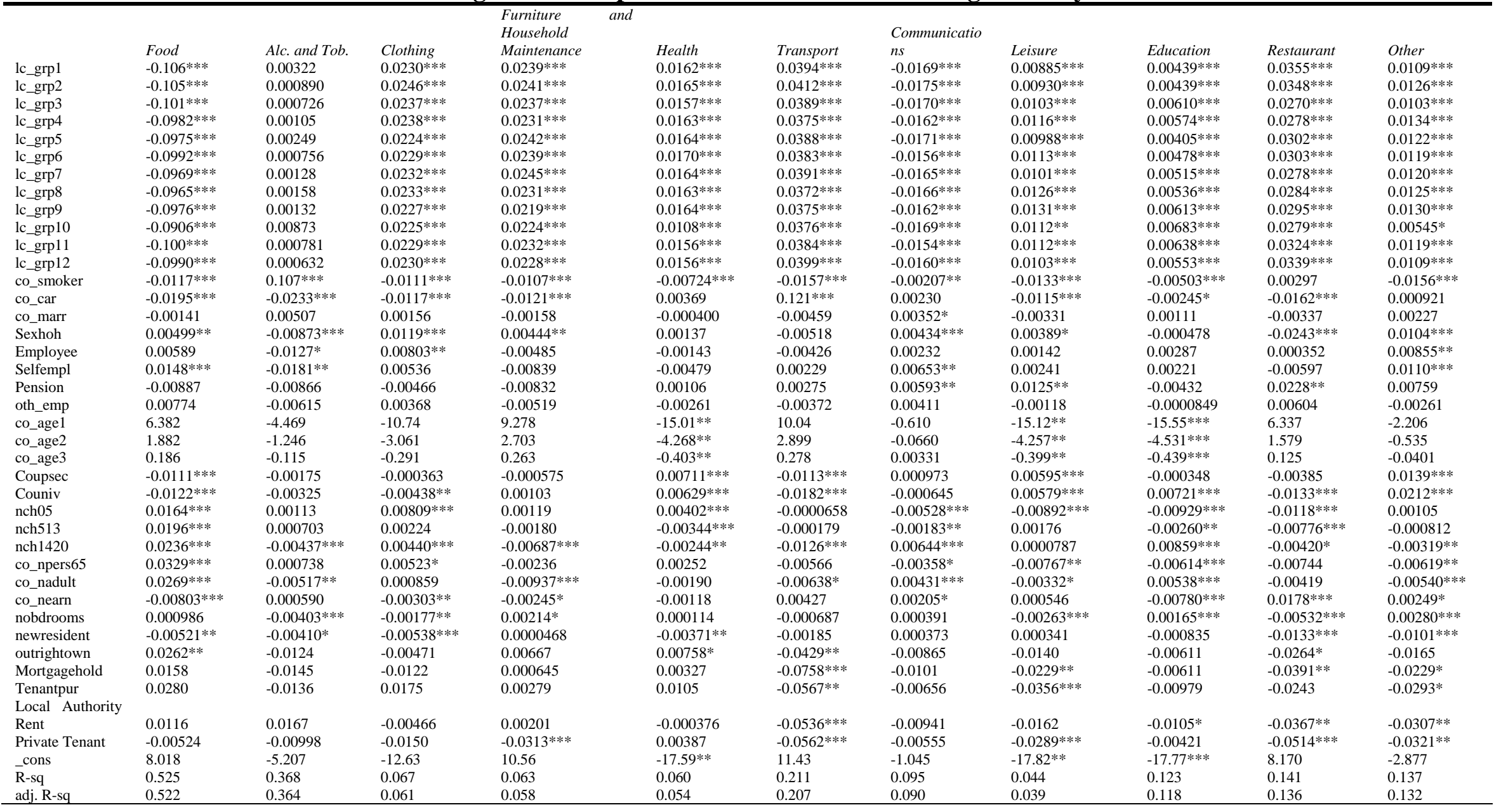

${ }^{15}$ Table A1 provides the list of explanatory variables -* $p<0.10,{ }^{* \star} p<0.05,{ }^{* \star \star} p<0.01$ 
Table A.4b: Regression Outputs from 2004 Household Budget Survey data

\begin{tabular}{|c|c|c|c|c|c|c|c|c|c|c|}
\hline & $\begin{array}{l}\text { Local } \\
\text { Authority } \\
\text { Rents }\end{array}$ & Private Rents & $\begin{array}{l}\text { Mortgage } \\
\text { Interest }\end{array}$ & $\begin{array}{l}\text { Materials for maint. } \\
\& \text { repair of dwelling }\end{array}$ & $\begin{array}{l}\text { Serv. for } \\
\text { maint. \& repair } \\
\text { of dwelling }\end{array}$ & $\begin{array}{l}\text { Refuse } \\
\text { Collection }\end{array}$ & Electricity & Natural Gas & Liquid fuels & $\begin{array}{l}\text { Solid fuels } \\
\end{array}$ \\
\hline lc_grp1 & $-0.00427 * * *$ & $-0.00304 * * *$ & 0.000712 & $0.00619 * * *$ & $0.00385^{*}$ & $-0.00375 * * *$ & $-0.0177 * * *$ & $-0.000914 *$ & $-0.0129 * * *$ & $-0.0113 * * *$ \\
\hline lc_grp2 & $-0.00406 * * *$ & $-0.00453 * * *$ & -0.00261 & $0.00596 * * *$ & $0.00522 * *$ & $-0.00392 * * *$ & $-0.0185 * * *$ & -0.000769 & $-0.0119 * * *$ & $-0.0109 * * *$ \\
\hline lc_grp3 & $-0.00367 * * *$ & $0.00447 * *$ & -0.00312 & $0.00555^{* * *}$ & 0.00334 & $-0.00369 * * *$ & $-0.0166 * * *$ & -0.000635 & $-0.0130^{* * *}$ & $-0.0112 * * *$ \\
\hline lc_grp5 & $-0.00424 * * *$ & $-0.00432^{* * *}$ & -0.00224 & $0.00555^{* * *}$ & 0.00346 & $-0.00379 * * *$ & $-0.0174 * * *$ & $-0.000887 *$ & $-0.0122^{* * *}$ & $-0.0104 * * *$ \\
\hline lc_grp6 & $-0.00388 * * *$ & $-0.00477 * * *$ & $-0.00350^{* *}$ & $0.00569^{* * *}$ & $0.00361 *$ & $-0.00370^{* * *}$ & $-0.0171^{* * *}$ & -0.000653 & $-0.0120^{* * *}$ & $-0.0103^{* * *}$ \\
\hline lc_grp7 & $-0.00390 * * *$ & $-0.00413 * * *$ & $-0.00361 * *$ & $0.00566^{* * *}$ & $0.00383 *$ & $-0.00374 * * *$ & $-0.0173 * * *$ & $-0.000877 *$ & $-0.0122 * * *$ & $-0.0104 * * *$ \\
\hline lc_grp8 & $-0.00368^{* * *}$ & $-0.00372^{* * *}$ & $-0.00484 * * *$ & $0.00544^{* * *}$ & $0.00396 *$ & $-0.00373 * * *$ & $-0.0175^{* * *}$ & $-0.000983 * *$ & $-0.0123^{* * *}$ & $-0.0104 * * *$ \\
\hline lc_grp9 & $-0.00359 * * *$ & $-0.00398 * * *$ & $-0.00630 * * *$ & $0.00541^{* * *}$ & $0.00498^{* *}$ & $-0.00372 * * *$ & $-0.0176 * * *$ & $-0.00113^{* *}$ & $-0.0122 * * *$ & $-0.0102 * * *$ \\
\hline lc_grp10 & $-0.00419 * * *$ & $-0.00417^{* *}$ & $-0.00377 * *$ & $0.00433^{* * *}$ & 0.00220 & $-0.00333 * *$ & $-0.0199 * * *$ & -0.000111 & $-0.0166^{* * *}$ & -0.000638 \\
\hline lc_grp11 & $-0.00340 * * *$ & $-0.00380 * * *$ & $-0.00500 * * *$ & $0.00613^{* * *}$ & $0.00426^{* *}$ & $-0.00366 * * *$ & $-0.0177^{* * *}$ & $-0.000982 * *$ & $-0.0126 * * *$ & $-0.0105 * * *$ \\
\hline lc_grp12 & $-0.00391 * * *$ & $-0.00348^{* * *}$ & $-0.00408 * * *$ & $0.00553^{* * *}$ & 0.00332 & $-0.00375 * * *$ & $-0.0174 * * *$ & $-0.000816^{*}$ & $-0.0125^{* * *}$ & $-0.0109 * * *$ \\
\hline co_smoker & $-0.000930 *$ & $-0.00428^{* * *}$ & $-0.00342 * *$ & $-0.00269 * * *$ & $-0.00530 * * *$ & 0.0000505 & $-0.00130 * * *$ & $-0.00143 * * *$ & 0.000177 & $0.00189 * *$ \\
\hline co car & $-0.00251^{* * *}$ & $-0.0125 * * *$ & -0.000661 & $-0.00300 * *$ & $-0.00520 * *$ & -0.000369 & -0.000206 & $-0.00571 * * *$ & $0.00477 * * *$ & $-0.00533 * * *$ \\
\hline co_marr & 0.000693 & $0.00915^{* * *}$ & 0.000735 & -0.000225 & -0.00267 & 0.000478 & 0.0000371 & -0.000385 & $-0.00255^{* *}$ & $-0.00382 * *$ \\
\hline Sexhoh & -0.0000547 & $-0.00331 * *$ & -0.00178 & -0.00107 & 0.00142 & 0.000190 & $0.000950 *$ & $0.00155^{* * *}$ & 0.000426 & -0.00125 \\
\hline Employee & -0.00365 & $-0.0116^{* *}$ & $0.00799 * *$ & -0.00294 & 0.00150 & 0.000564 & -0.00149 & 0.000731 & 0.000722 & 0.00198 \\
\hline Selfempl & -0.00360 & $-0.00931 *$ & $0.00646 *$ & -0.00283 & -0.00359 & -0.000988 & -0.0000662 & -0.00101 & $0.00297 *$ & $0.00459 * *$ \\
\hline Pension & -0.00401 & -0.00757 & 0.00348 & -0.00155 & $-0.00863 * *$ & $0.00153^{*}$ & -0.00141 & $0.00420^{* *}$ & -0.00215 & -0.00196 \\
\hline oth_emp & $-0.00662 *$ & -0.00579 & $0.00866 * *$ & -0.00212 & -0.00111 & 0.000212 & -0.000925 & 0.000140 & 0.00251 & $0.00516^{* *}$ \\
\hline co_age1 & $-6.624^{* * *}$ & -5.879 & $26.33^{* * *}$ & -0.514 & 4.881 & -1.642 & 0.130 & 0.164 & $9.719 * * *$ & 5.432 \\
\hline co_age2 & $-1.909 * * *$ & -1.629 & $7.358^{* * *}$ & -0.133 & 1.387 & -0.476 & 0.0559 & 0.0647 & $2.734^{* * *}$ & 1.539 \\
\hline Couniv & 0.000988 & 0.00172 & $0.0118^{* * *}$ & -0.00147 & -0.00182 & $0.000888^{* * *}$ & $0.00171^{* * *}$ & $0.000872 *$ & -0.000992 & $-0.00341^{* * *}$ \\
\hline nch05 & $-0.00168^{* *}$ & 0.00218 & 0.00152 & -0.000395 & -0.00194 & 0.0000436 & $0.00226^{* * *}$ & $0.000933^{* *}$ & 0.000687 & -0.0000548 \\
\hline nch513 & $-0.00116^{* *}$ & -0.00141 & $-0.00375^{* *}$ & 0.000170 & $-0.00220 *$ & 0.0000850 & $0.00193^{* * *}$ & 0.000215 & -0.000104 & 0.000330 \\
\hline nch1420 & $-0.00136 * * *$ & 0.00100 & $-0.00557 * * *$ & $-0.00205^{* * *}$ & $-0.00330^{* * *}$ & -0.0000130 & $0.00163^{* * *}$ & $-0.000487 *$ & 0.000424 & 0.000417 \\
\hline co_npers65 & -0.000627 & -0.000873 & $0.00482 * *$ & 0.0000574 & -0.00210 & $-0.00123^{* * *}$ & $-0.00220 * *$ & -0.000165 & 0.0000282 & -0.000402 \\
\hline Co_nadult & $0.00130^{*}$ & -0.00260 & 0.00149 & -0.00101 & $-0.00433 * * *$ & -0.000210 & $0.00252^{* * *}$ & -0.000328 & 0.000316 & $0.00119 *$ \\
\hline co_nearn & $-0.00122 * * *$ & -0.000608 & -0.000132 & 0.000164 & $-0.00234 * *$ & 0.0000288 & $-0.000626 *$ & 0.000161 & 0.0000325 & -0.000761 \\
\hline Nobdrooms & 0.000114 & -0.000869 & 0.000856 & 0.000267 & $0.00277^{* * *}$ & $0.000231 *$ & $0.00104^{* * *}$ & $-0.00104 * * *$ & $0.00285^{* * *}$ & 0.000173 \\
\hline Newresident & 0.000840 & $0.00239 * *$ & $0.0450 * * *$ & $0.00208^{*}$ & $-0.00287 *$ & 0.0000639 & $-0.00138 * *$ & $-0.00135 * * *$ & $0.00179 * *$ & $-0.00259 * * *$ \\
\hline Outrightown & $0.00158^{* *}$ & $0.00673^{* * *}$ & $0.0435 * * *$ & 0.000963 & $0.0195^{* * *}$ & 0.00153 & 0.00200 & -0.00102 & $0.00830^{* *}$ & 0.00825 \\
\hline Mortgagehold & $0.00389 * * *$ & $0.00696^{* * *}$ & $0.142^{* * *}$ & -0.00247 & $0.0163^{* * *}$ & 0.00204 & 0.00161 & 0.00122 & 0.00570 & 0.00662 \\
\hline Tenantpur & $0.00212^{* *}$ & 0.00247 & $0.100 * * *$ & -0.00434 & 0.00664 & -0.000866 & 0.00158 & 0.00667 & -0.00480 & 0.00781 \\
\hline Local Authority & & & & & & & & & & \\
\hline Rent & $0.104 * * *$ & -0.00335 & $0.0208 * * *$ & -0.00397 & -0.000417 & 0.00209 & 0.00203 & $0.00492 * *$ & $-0.00651^{*}$ & $0.0124^{* *}$ \\
\hline Private Tenant & $0.00140 *$ & $0.259 * * *$ & $-0.0172 * * *$ & $-0.00875^{*}$ & 0.000152 & -0.000470 & 0.00137 & -0.000762 & -0.000593 & 0.00216 \\
\hline _cons & $-7.623^{* * *}$ & -7.023 & $31.22 * * *$ & -0.678 & 5.732 & -1.856 & 0.202 & 0.137 & $11.58^{* * *}$ & 6.473 \\
\hline$\overline{\mathrm{R}}$-sq & 0.691 & 0.776 & 0.590 & 0.018 & 0.073 & 0.092 & 0.211 & 0.071 & 0.163 & 0.131 \\
\hline adj. R-sq & 0.689 & 0.775 & 0.587 & 0.012 & 0.068 & 0.087 & 0.207 & 0.066 & 0.158 & 0.126 \\
\hline
\end{tabular}




\section{BIBLIOGRAPHY}

Amiel, Y. \& Creedy, J. \& Hurn, S., 1999. "Measuring Attitudes towards Inequality," Scandinavian Journal of Economics, Blackwell Publishing, vol. 101(1), pp. 83-96

Atkinson A.B. 1970. “On the Measurement of Inequality,” Journal of Economic Theory 2, pp. 244-263, Faculty of Economics and Politics, University of Cambridge, England

Bargain O., Donni O. \& Gbakou M., 2010. "The Measurement of Child Costs: Evidence from Ireland," The Economic and Social Review, Economic and Social Studies, vol. 41(1), pp. 1-20.

Barnett, W. A., Seck, O., 2008. "Rotterdam model versus almost ideal demand system: will the best specification please stand up?," Journal of Applied Econometrics, John Wiley \& Sons, Ltd., vol. 23(6), pages 795-824.

Blinder, A., 1978, On Making the tradeoff between Equality and Efficiency Operational, Paper presented at the meetings of the Allied Social Science Associations, Chicago, IL

Crawford, I. and Z. Smith, 2002. "Distributional Aspects of Inflation,” The Institute for Fiscal Studies.

Creedy, J. and J. Van de Ven, 1996, “The distributional effects of inflation in Australia,” Research Paper 537, The University of Melbourne

Creedy, J. 1998, "The welfare effect on different income groups of indirect tax changes and inflation in New Zealand," University of Melbourne, The Economic Record, Vol. 74, No.227, pp 373-83

Creedy, J. 2001 "Indirect Tax Reform and the Role of Exemptions,” Fiscal Studies, vol. 22, no. 4, pp. 457-486

Deaton, A. 1974. "A reconstruction of the empirical implications of additive preferences,” Economic Journal, Vol. 84; pp. 338-348.

Deaton, A. S. and J. Muellbauer 1980. An Almost Ideal Demand System, American Economic Review, 70, 312-326.

Dixon, P.B. and C. Lluch 1977, "Durable goods in the extended linear expenditure system,” Review of Economic Studies 44, pp 381-4

Frisch, R. 1959, “A Complete Scheme for Computing All Direct and Cross Demand Elasticities in a Model with Many Sectors” Econometrica, Vol. 27, No. 2. (Apr., 1959), pp. 177-196.

Goni, E., Lopez, H. and Servén, L., 2006, “Getting Real About Inequality: Evidence from Brazil, Colombia, Mexico, and Peru”, World Bank Policy Research Working Paper No. 3815.

Hobijn, B. and D. Lagakos, 2005, "Inflation Inequality in the United States" Review of Income and Wealth.

Irvine, I., and C. McCarthy, 1978, "Expenditure Patterns and the Welfare Effects of Inflation: Estimates of a 'True' Cost-of-Living Index”, The Economic and Social Review, Vol. 9, No. 2, January, pp. 157-165. 
King, M., 1983 “Welfare Analysis of Tax Reforms Using Household Data,” Journal of Public Economics, Vol. 21., pp. 183-214.

Lahiri, S., M. Babiker and R.S. Eckaus, 2000: The Effects of Changing Consumption Patterns on the Costs of Emission Restrictions. MIT Joint Program on the Science and Policy of Global Change, Report 64, Cambridge, Massachusetts.

Liberati, P., 2001, "The Distributional Effect of Indirect Tax Changes in Italy," International Tax and Public Finance, Vol. 8, pp. 27-51.

Madden, D. 1995, “An analysis of indirect tax reform in Ireland in the 1980s”, Fiscal Studies, vol. 16, no. 1, pp. 18-37.

Murphy E. and E. Garvey 2004, “A Consumer Price Index for low-income households in Ireland (1989-2001)”, Combat Poverty Agency, Working Paper 04/03.

Murphy, Eithne and Garvey, Eoghan (2008) 'The inadequacy of cost of living indices based on subjective preferences: an ethical and methodological critique', International Review of Applied Economics, 22: 6, 745 -754

Newbery, D., 1995, “The Distributional Impact of Price Changes in Hungary and the United Kingdom,” The Economic Journal, Vol. 105, No. 431, pp. 847-863.

Lundberg, S.J. \& Pollak, R.A. \& Wales, T.J., 1994. "Do Husbands and Wives Pool Their Resources? Evidence from U.K. Child Benefit," Discussion Papers in Economics at the University of Washington 94-6, Department of Economics at the University of Washington

Oosthuizen, M. 2007. "Consumer Price inflation across the income distribution in South Africa”. Development Policy Research Unit Working Paper 07/129.

Pollak, Robert A \& Wales, Terence J, 1978. "Estimation of Complete Demand Systems from Household Budget Data: The Linear and Quadratic Expenditure Systems," American Economic Review, American Economic Association, vol. 68(3), pages 348-59

Powell, A. 1974. "Empirical Analysis of Demand Systems”, Lexington: Lexington Books

Roberts, K. 1980, "Price-Independent welfare prescriptions", Journal of Public Economics, Vol.18, pp. 277-297.

Stone, J. R. N., 1954. “Linear Expenditure System and Demand Analysis, An Application to Pattern of British Demand,” Econometrica. 64: 511-527.

Theil, H. 1976, Theory and Measurement of Consumer Demand, Vol. 2, North Holland

Whelan C. T. \& Maître B., 2010. "Protecting the vulnerable: poverty and social exclusion in Ireland as the economic crisis emerged," The Economic and Social Review, Vol 41 No 4, pp.501-525 